Article

\title{
Critical Elements in Supergene Phosphates: The Example of the Weathering Profile at the Gavà Neolithic Mines, Catalonia, Spain
}

\author{
Yael Díaz-Acha ${ }^{1}$, Marc Campeny ${ }^{1,2, *(0)}$, Esperança Tauler ${ }^{2}{ }^{\circledR}$, Josep Bosch ${ }^{3}$, \\ Joan Carles Melgarejo ${ }^{2}(0)$, Antoni Camprubí ${ }^{4}$, Cristina Villanova-de-Benavent ${ }^{2}{ }^{\circledR}$, \\ Susana E. Jorge-Villar 5,6 (D), Iria Díaz-Ontiveros ${ }^{1}$, David Fernández-Lluch ${ }^{1}$, \\ Joaquín A. Proenza ${ }^{2}$ (D) Aleu Andreazini ${ }^{2}$ and Míriam Pastor ${ }^{2}$ \\ 1 Museu de Ciències Naturals de Barcelona, Parc de la Ciutadella s/n, 08003 Barcelona, Spain; \\ ydiaz@bcn.cat (Y.D.-A.); idiazont@gmail.com (I.D.-O.); davife@gmail.com (D.F.-L.) \\ 2 Departament de Mineralogia, Petrologia i Geologia Aplicada, Facultat de Ciències de la Terra, Universitat de \\ Barcelona, Martí i Franquès s/n, 08028 Barcelona, Spain; esperancatauler@ub.edu (E.T.); \\ joan.carles.melgarejo.draper@ub.edu (J.C.M.); c.villanova-de-benavent@brighton.ac.uk (C.V.-d.-B.); \\ japroenza@ub.edu (J.A.P.); aleuan@gmail.com (A.A.); mpaol22@gmail.com (M.P.) \\ 3 Museu de Gavà, Plaça de Dolors Clua 13, 08850 Gavà, Spain; jbosch@gava.cat \\ 4 Instituto de Geología, Universidad Nacional Autónoma de México (UNAM), Ciudad Universitaria, \\ Coyoacán 04510, CDMX, Mexico; camprubitaga@gmail.com \\ 5 Department of Civil Engineering, University of Burgos, Calle Complutense 2, 09001 Burgos, Spain; \\ susanajorgevillar@hotmail.com \\ 6 Facultad de Educación, Universidad de Burgos, C/Villadiego 1, 09001 Burgos, Spain \\ * Correspondence: mcampenyc@bcn.cat; Tel.: +34-93-256-2188
}

Received: 22 October 2019; Accepted: 13 December 2019; Published: 18 December 2019

\begin{abstract}
The essential role of Critical Elements (CE) in 21st century economy has led to an increasing demand of these metals and promotes the exploration of non-conventional deposits such as weathering profiles. The present work is focused on the study of a weathering profile located at the Archaeological Park of the Gavà Neolithic Mines, Barcelona, Catalonia, Spain. In the Gavà deposit, acid and oxidising meteoric fluids generated intense weathering during the early Pleistocene, affecting series of Llandoverian black shales and associated syn-sedimentary phosphates. The circulation of these acid fluids at deeper levels of the profile generated supergene vein-like mineralisations comprised of secondary phosphates (e.g., variscite, perhamite, crandallite, phosphosiderite) and sulphates (e.g., jarosite, alunite). This supergene mineralisation is significantly enriched in certain CE (e.g., Ga, Sc, REE, In, Co and Sb) that were mobilised from host rock components and later hosted in the crystal lattice of supergene minerals. Weathering processes and corresponding supergene enrichment of $\mathrm{CE}$ at the Gavà deposit could be used as an example to determine exploration guidelines of $\mathrm{CE}$ in weathering profiles and associated supergene phosphates worldwide.
\end{abstract}

Keywords: critical elements; weathering; supergene mineralisation; phosphates; Gavà

\section{Introduction}

In 2017, the European Commission assessed a list of 61 raw materials (including metallic ores, biogenic products and industrial minerals) on their criticality for the EU. These critical elements (CE) were selected considering their economic relevance for the European industry and their relative supply risk. A group of 27 raw materials was determined as critical for the EU according to these two criteria [1]. 
The essential role of $\mathrm{CE}$ in the development of 21st century industry (e.g., electric cars, green energy production, LED lamps, optical fibre, etc.) led to an increasing demand of these metals in the last few years that will probably continue in the near future [2-6].

In this context, European governments promote the exploration of new resources of $\mathrm{CE}$ with special interest in the study of non-conventional mineral deposits that include secondary sedimentary formations such as weathering profiles [7], among others.

The exploration of CE in this type of geological environments is mainly focused on the study of laterites in which significant concentrations of critical elements such as rare earth elements (REE), Sc, or platinum group elements (PGE) have recently been reported in different localities worldwide [8-16]. Indeed, weathering processes such as lateritisation alter bedrock minerals and lead to significant changes in the geochemical distribution of several elements.

The study of CE distribution in weathering profiles is essential to understanding their solubility, mobility, and fractionation [17], and thus to determine the conditions required to generate a potential CE deposit. In addition, new constrains on CE distribution and fractionation will enhance current knowledge of the geochemical behaviour of some of these elements in order to trace edaphic and weathering processes $[18,19]$.

In this study, the evolution and mobility of $C E$ have been investigated across a Neogene weathering profile located in Gavà (near Barcelona, Catalonia, Spain) (Figure 1). The studied 20-metre thick profile developed from the alteration of Llandoverian black shales that contain interbedded primary syn-sedimentary phosphate nodules and layers. Oxidation weathering and associated percolating fluids produced secondary phosphate veins that were exploited as lapidary material by means of underground mining during the Neolithic age [20-25]. Nearly 90 mines with their corresponding galleries, shafts and trenches dated from $5800-5700 \mathrm{BP}$ have been exposed by archaeological excavations in Gavà [26-36]. These mines are amongst the oldest underground mining works in the world and provide essential information about mining techniques used during prehistoric times [21]. The Gavà Neolithic mines were dug out in the weathering profile and consist of pits and tunnels at different levels achieving up to $15 \mathrm{~m}$ in depth [30]. Thus, these mines provide an excellent opportunity to study the chemical variations according to depth occurring in phosphate mineralisation as well as in host rocks.

Some of these mining galleries are open to the public on the site of the Archaeological Park of the Gavà Neolithic Mines (APGNM) [37]. Further weathering-derived rocks in the Gavà area were also mined for iron since the Iberian-Roman period [38].

The textural, mineralogical, and geochemical study of the Gavà weathered sequence and associated supergene vein-like mineralisation may provide relevant information about the mobility and redistribution of $\mathrm{CE}$ during weathering in phosphate-rich environments. This understanding will eventually be useful in the exploration of non-conventional deposits of $\mathrm{CE}$ associated with weathering profiles related to primary phosphates.

\section{Geological Setting}

The study area is located in the city of Gavà, $20 \mathrm{~km} \mathrm{SE}$ of Barcelona, in the NE of the Iberian Peninsula (Figure 1). The Gavà area is included in the Catalan Coastal Range (CCR), a NE-SW mountain chain flanked by the Mediterranean Sea to the south and the Ebro Basin to the north, and divided into two different mountain systems (Littoral and Pre-littoral), separated by the Pre-littoral Depression $[39,40]$ (Figure 1). The present relief of the CCR was formed in the late Eocene during the Alpine orogeny. However, outcropping materials are part of the Palaeozoic basement that was metamorphosed and deformed during the Hercynian and Alpine orogenies [41] (Figure 1).

Although Mesozoic sediments are found in the NW area of Gavà, most of the city is built on the Palaeozoic basement, which is partly covered by unconformable levels of Quaternary calcretes and reddish clays with carbonate nodules, up to $3 \mathrm{~m}$ thick [22,42].

Palaeozoic basement lithologies of the central part of the CCR consist of Ordovician, Silurian, Devonian and Carboniferous materials: (1) Ordovician slates and quartzites; (2) Llandoverian 
sulphide-rich black shales interbedded with centimetre-thick layers of syn-sedimentary apatite and chert; (3) Wenlockian black shales interbedded with centimetric quartzite layers; (4) Ludlowian black shales with interbedded limestone lenses; (5) Pridolian nodular limestones which are partially dolomitised or ankeritised; (6) Lockovian black schists followed by interbedded limestones, reddish shales and green to bluish marls; (7) Lower Carboniferous cherts, greenish shales and greywackes [20-22,25,38,43].

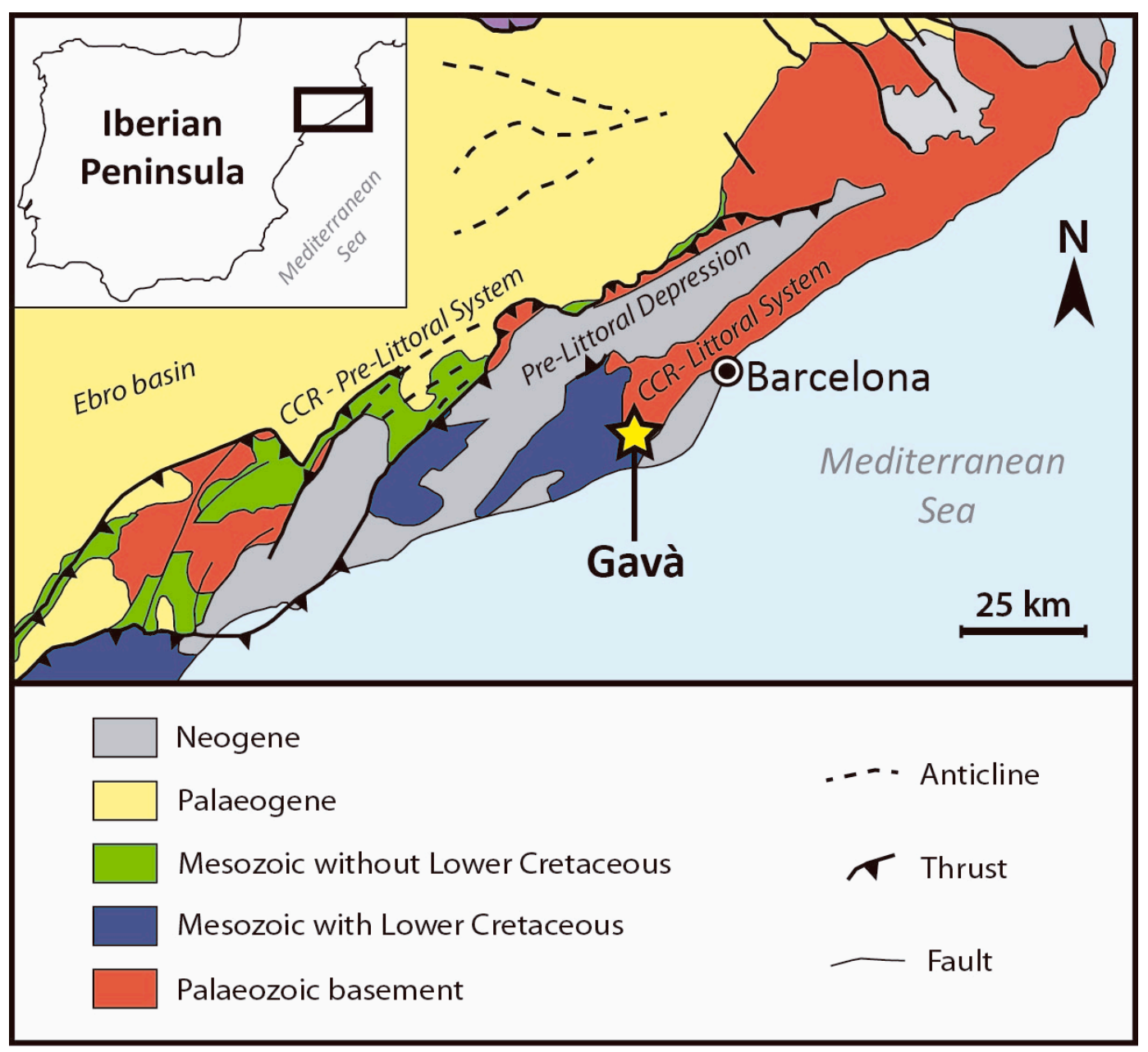

Figure 1. Location map of the study area including the main geological units of the Catalan Coastal Ranges (CCR).

During the Hercynian orogeny, the Palaeozoic series was affected by two generations of tight folds roughly trending NW-SE but with opposite vergence. The latter are mostly detachment folds and display two generations of axial plane cleavages. The fold-related thrusts and cleavage provided channels for the circulation of hydrothermal fluids which produced quartz veins, as well as dolomitisation and ankeritisation in Palaeozoic limestones. The series was affected only by very low-grade metamorphism in this sector of the Catalan Coastal Ranges; intrusive rocks and contact metamorphism are absent. During the Palaeogene, the Alpine deformation produced the development of transcurrent NE-SW faults and associated joint systems. These faults were reactivated as normal faults during the Neogene regional extension $[39,42,43]$.

The Palaeozoic materials are unconformably covered by Quaternary calcretes overlaid by reddish clays with carbonate nodules, which add up to $3 \mathrm{~m}$ in thickness [22]. Below this Quaternary unconformity, the Palaeozoic series displays strong supergene weathering, with a mineral composition that depends on the degree of weathering of the affected material. The carbonate-rich series is partly 
replaced by karstic iron oxyhydroxides, which were mined during Iberian times for iron [38]. In contrast, the black shales become progressively paler (grey) at $15 \mathrm{~m}$ below the unconformity. This change in colour has been explained by the destruction of organic matter contained in black shales [25]. These fluids also led to the formation of secondary phosphates [25].

The supergene phosphate mineralisation studied is distributed along vertical veins hosted by Llandoverian shales. Supergene phosphates are also associated with secondary sulphates (e.g., jarosite, alunite and baryte). Dating of alunite by K-Ar yielded an Early Pleistocene age (1.20 $\pm 0.05 \mathrm{Ma}$; [21]) that corresponds to the weathering episode. Variscite mineralisation is revealed by the Neolithic mining galleries [20,21,25]. Over 90 Neolithic mines have been reported to date in the Gavà area. The most important cluster of galleries has been preserved and has become an on-site museum at the APGNM, where sampling for the present study was carried out (Figure 2).

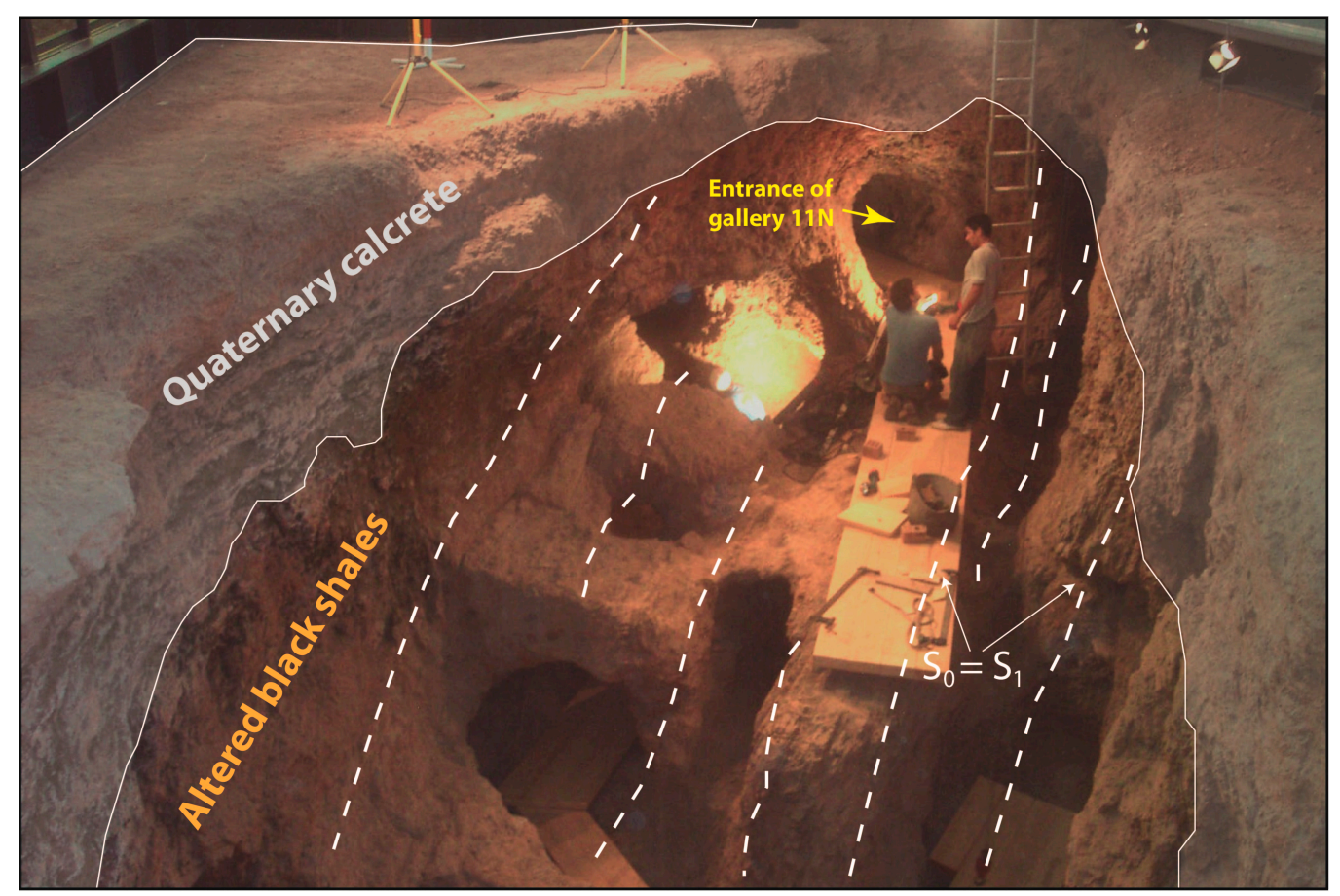

Figure 2. View from above the studied profile in the Neolithic mining area of the Archaeological Park of the Gavà Neolithic Mines (APGNM). Note the Neolithic pits and tunnels. The vertical dip of Silurian bleached shales (S0) and the subparallel, main Hercynian cleavage (S1) are indicated in the image, as well as the unconformity with Quaternary calcretes.

\section{Materials and Methods}

\subsection{Sampling}

A set of 14 rock samples was obtained from a geological section that shows the greatest extent of the weathering profile at the location of gallery 11N of the APGNM, which crosscuts the seven levels of the gallery (Figure 3). The study includes 6 samples of supergene mineralisation veins obtained at different depths, and 7 samples of the host Llandoverian bleached shales, as well as an additional sample of the overlaying Quaternary calcrete.

\subsection{X-ray Diffraction (XRD)}

The bulk mineralogical composition of altered shales and associated phosphate veins was studied by means of X-ray diffraction (XRD). Samples were ground in an agate mortar to produce homogenised powder and randomly oriented material, with a particle size below $40 \mu \mathrm{m}$. The XRD analyses of 
phosphates were performed using a PANalytical X'Pert PRO Alpha1 diffractometer at the Scientific and Technological Centres of the University of Barcelona (CCiT-UB, Barcelona, Spain). The diffractometer used an incident $\mathrm{Cu} \mathrm{K} \alpha 1$ radiation at $45 \mathrm{kV}$ and $40 \mathrm{~mA}$, and was equipped with a PS detector with an amplitude of $2.113^{\circ}$. Diffractograms were obtained by scanning samples from $4^{\circ}$ to $80^{\circ}(2 \theta)$, with a scan time of $50 \mathrm{~s}$, a step size of $0.017^{\circ}(2 \theta)$, and variable divergence slit. XRD measurements of host rock samples were carried out using a Bruker-AXS D8-A25 Advance diffractometer at the X-ray diffraction laboratory of the Jaume Almera Institute of Earth Sciences (Barcelona, Spain). The diffractometer was equipped with a $\mathrm{Cu}$ X-ray tube of up to $3 \mathrm{~kW}$ with point/line focus, large diameter goniometer (560 mm), and ultra-fast PSD detector (0D and 1D modes). XRD scans were acquired between $4^{\circ}$ and $65^{\circ}(2 \theta)$, at $0.02^{\circ}$ steps. Mineral identification and semi-quantitative results were obtained using the $X^{\prime}$ Pert HighScore search-match software with Powder Diffraction File 2.0 from International Centre for Diffraction Data (ICDD). Semi-quantitative mineral phase analyses were obtained by full refinement profile using the software TOPAS 4.2.

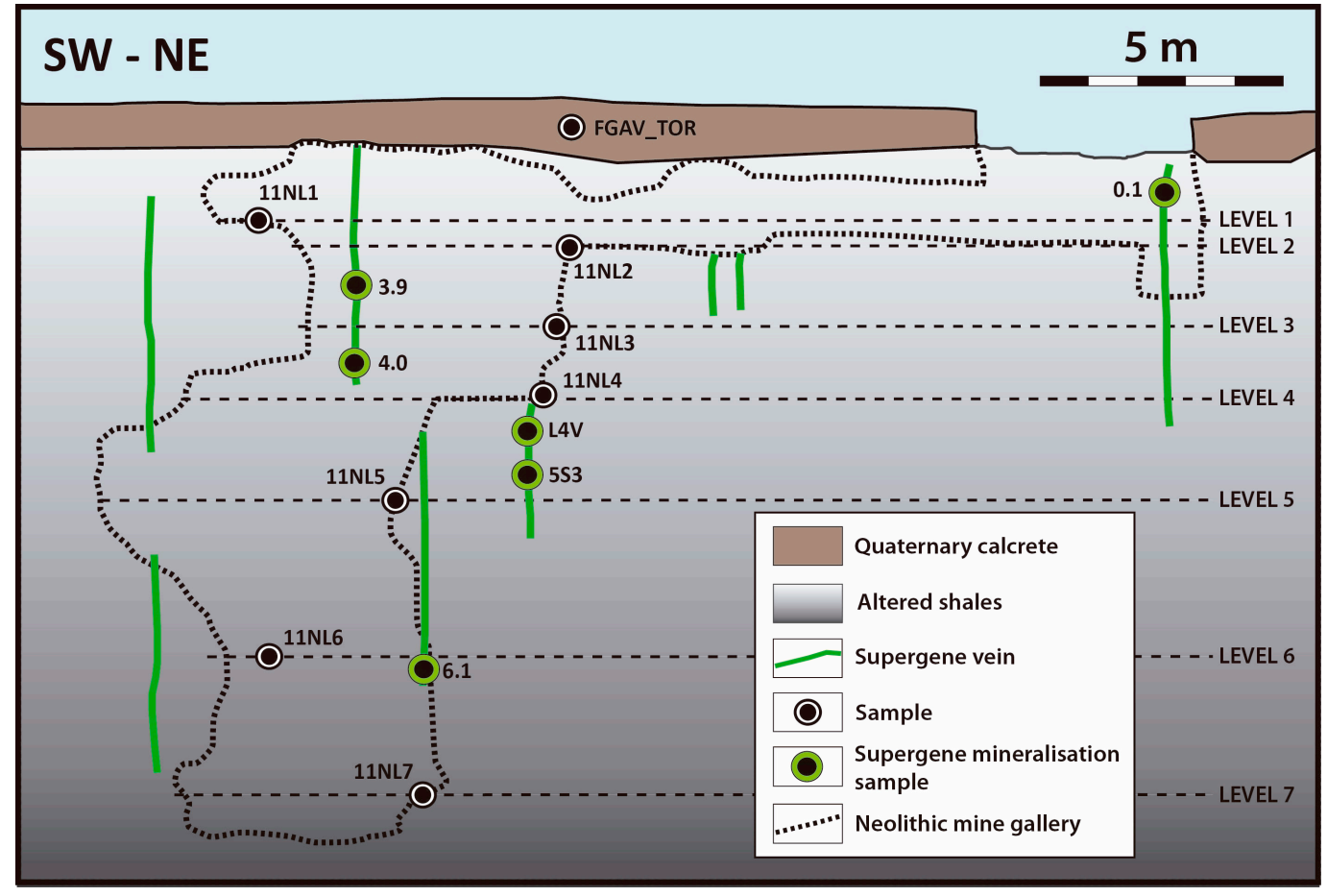

Figure 3. Schematic profile of mine gallery $11 \mathrm{~N}$ from the Archaeological Park of the Gavà Neolithic Mines (APGNM). Mining levels are detailed, as well as the location of the main supergene phosphate veins and the samples used in this study.

\subsection{Scanning Electron Microscopy (SEM) and Field Emission Scanning Electron Microscopy (FE-SEM)}

The set of 6 samples of supergene phosphate veins were prepared as polished thin sections for textural and mineralogical studies at the Laboratory of Geological and Paleontological Preparation (LPGiP) of the Natural Sciences Museum of Barcelona (Barcelona, Spain). These thin sections were examined in an environmental scanning electron microscope (SEM), Quanta 200 FEI, XTE 32/D8395, equipped with an energy-dispersive spectrometer (EDS) at the CCiT-UB (Barcelona, Spain). Operating conditions were $15-20 \mathrm{kV}$ accelerating voltage and $5 \mathrm{nA}$ beam current. Presented electron micrographs were obtained with a field emission scanning electron microscope (FE-SEM) JEOL JSM-7100 at the CCiT-UB (Barcelona, Spain). 


\subsection{Electron Probe Microanalysis (EPMA)}

Electron probe microanalyses (EPMA) were performed on a JEOL JXA-8230 electron microprobe with five wavelength-dispersive spectrometers (WDS), an energy dispersive spectrometer (EDS), and a silicon-drift EDS detector, available at the CCiT-UB (Barcelona, Spain).

Spot analyses were carried out with a $15 \mathrm{kV}$ accelerating voltage, a $10 \mathrm{nA}$ beam current, and a focused beam, in order to achieve the best lateral resolution. Counting times ranged from 20 to $40 \mathrm{~s}$ for both peaks and background. Analytical standards included natural and synthetic silicates, oxides and rare earth elements (REE) glasses as follows: diopside (Ca K $\alpha$, Si K $\alpha$ ), spinel ( $\mathrm{Al} \mathrm{K \alpha}$ ), $\mathrm{RbTiOPO}_{4}(\mathrm{P}$ $K \alpha$ ), periclase $(\operatorname{Mg} K \alpha)$, hematite $(F e K \alpha)$, orthoclase $(K K \alpha)$ and celestine $(S K \alpha)$. The XPP correction procedure was used to convert specimen intensity ratios into concentrations. Structural formulae were calculated considering $\mathrm{Fe}$ as $\mathrm{Fe}^{3+}, 4$ oxygens for variscite and phosphosiderite, 7 oxygens for halloysite, 12 oxygens for apatite, and 59 oxygens for perhamite.

\subsection{Bulk Rock Geochemistry}

Major, minor, and trace element (including REE) analyses of the 14 selected samples were carried out at ActLabs Activation Laboratories Ltd. (Ontario, Canada). Major elements $\left(\mathrm{SiO}_{2}, \mathrm{TiO}_{2}, \mathrm{Al}_{2} \mathrm{O}_{3}\right.$, $\mathrm{Fe}_{2} \mathrm{O}_{3}, \mathrm{MnO}, \mathrm{MgO}, \mathrm{CaO}, \mathrm{Na}_{2} \mathrm{O}, \mathrm{K}_{2} \mathrm{O}, \mathrm{P}_{2} \mathrm{O}_{5}$ ) and loss on ignition (LOI) were performed by fusion inductively coupled plasma emission spectroscopy (ICP-ES). Trace elements, including Sc, Be, $\mathrm{V}, \mathrm{Cr}$, $\mathrm{Co}, \mathrm{Ni}, \mathrm{Cu}, \mathrm{Zn}, \mathrm{Ga}, \mathrm{Ge}, \mathrm{As}, \mathrm{Rb}, \mathrm{Sr}, \mathrm{Zr}, \mathrm{Nb}, \mathrm{Mo}, \mathrm{Ag}$, In, Sn, Sb, Cs, Ba, Bi, REE (La-Lu, Y), Hf, Ta, W, Tl, $\mathrm{Pb}$, Th and $\mathrm{U}$, were performed by fusion inductively coupled plasma mass spectrometry (ICP-MS). Supergene phosphate samples were previously crushed and examined under the microscope in order to select pure fragments.

\section{Structure of the Deposit}

The APGNM consists of a network of four connected mines, excavated in weathered Llandoverian shales through a complex system of tunnels and shafts. The distribution of tunnels depends directly on the occurrence of supergene phosphate veins, mainly composed of variscite [25]. The altered Llandoverian shales are covered by 1.5-2 m-thick Quaternary calcrete, which is well lithified. Thus, the calcrete was generally used as the roof of the Neolithic tunnels' top level (Figures 2 and 3). The Llandoverian shales of the mining area occur on the inverted flank of first-stage Hercynian folds. Most of the beds are subvertical with penetrative slaty cleavage that is subparallel to the bedding due to deformation by Alpine faulting. As a result, the deformation of the fold axis during the first tectonic event (stage 1) accounts for the orientation variations of the deposit between NW-SE and WSW. The latter are the directions followed by apatite beds replaced by variscite (Figure 4a), and some of the tunnels accordingly follow these directions.

Llandoverian shales occurring across the Catalonian Coastal Ranges are characteristically black due to their organic matter content. However, in the APGNM profile, this lithology is completely bleached due to intense weathering that produced the alteration of organic matter, hence its light grey colour (Figure 4a-f), which darkens with depth.

Two dense systems of subvertical veinlets crosscut the above materials (Figure $4 \mathrm{~b}-\mathrm{f}$ ). One system consists of veinlets that follow the slaty cleavage and are therefore subparallel to the stratification. These veinlets are up to a few millimetres wide. The other system consists of joints that are perpendicular to the fold axis and may reach up to $1-2 \mathrm{~cm}$ in width. This is why the paths of the rest of the tunnels have NNW-SSE and NE-SW orientations. All these veinlets are mainly filled at the top of the deposit, up to $2 \mathrm{~m}$ below the unconformity, by yellowish green or white clay minerals. Variscite displays a pale olive-green colour in the upper and intermediate levels, and tends to become bluish green at the deeper parts of the deposit. In general, phosphate associations occur along with secondary sulphates as well as with cryptocrystalline quartz (Figure $4 \mathrm{c}, \mathrm{d}$ ) and clay minerals. 

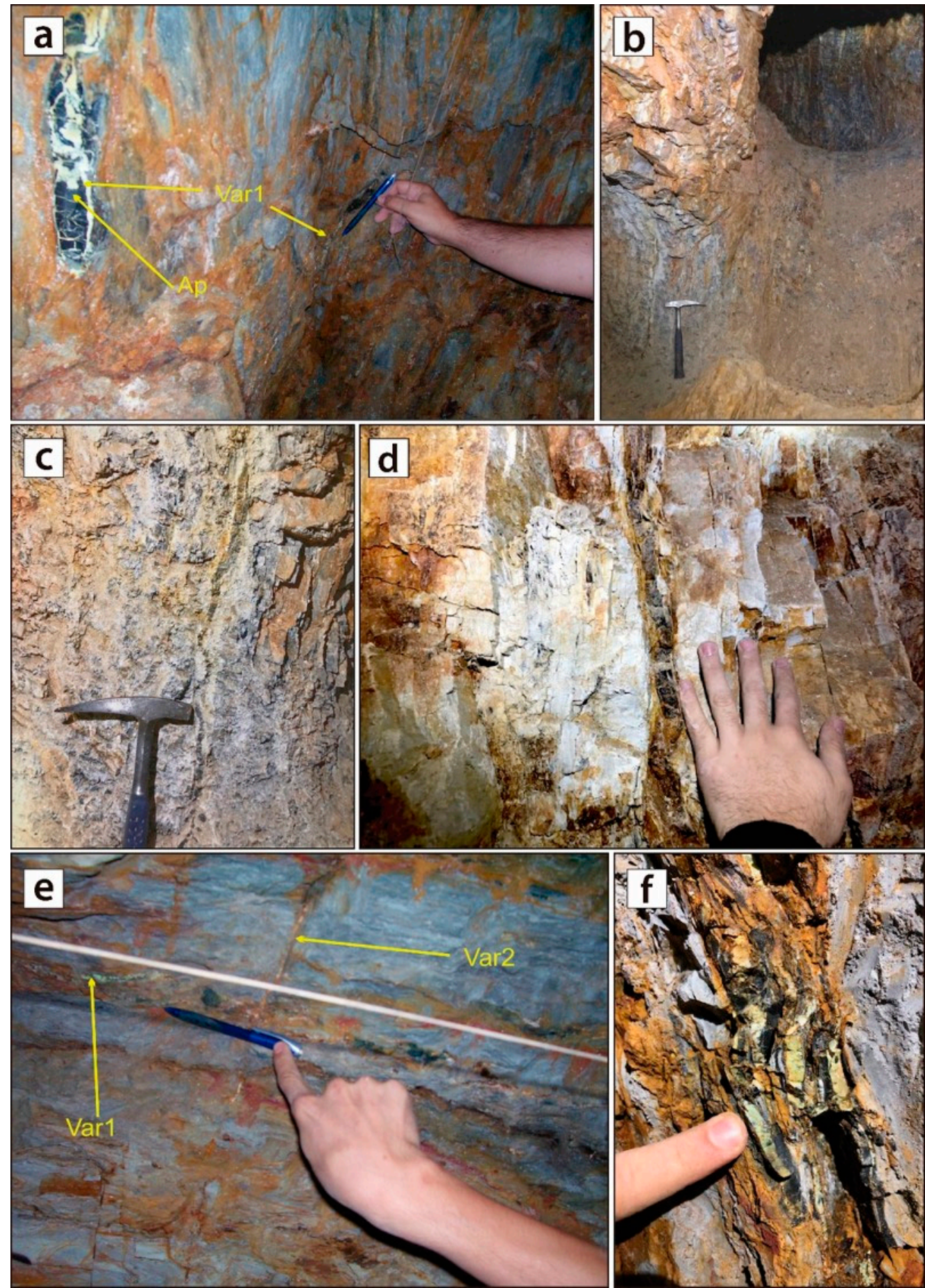

Figure 4. (a) Replacement of a vertical apatite bed (Ap) with variscite (Var1); (b) Neolithic tunnel following veinlets with variscite and black, cryptocrystalline quartz within grey shales; (c,d) Details of the above veinlets; (e) Two generations of variscite veinlets, the first following the slaty cleavage (Var1), and the second in vertical joints (Var2); (f) Detail of variscite veins in bleached shales.

\section{Mineral Characterization}

The X-ray diffractograms of the hosted rock samples along the profile show broad diffraction peaks, which indicate poor crystallinity of the mineralogy (Figure 5). 


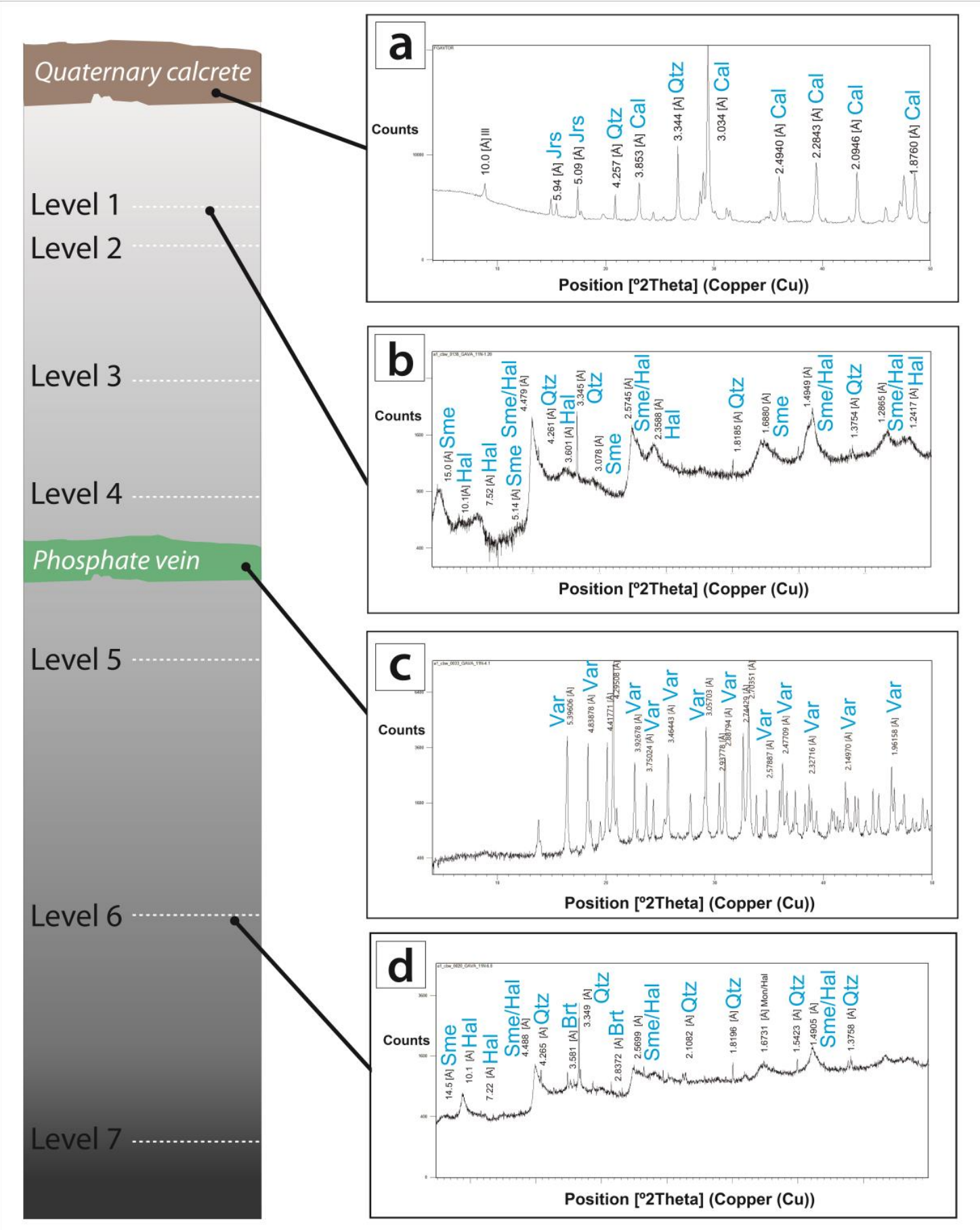

Figure 5. Schematic weathering profile of the Gavà area and corresponding X-ray powder diffractograms of selected representative samples from different profile levels. (a) Quaternary calcrete with $75 \mathrm{wt}$. \% of calcite (Cal), 14 wt. \% of quartz (Qtz), 5 wt. \% of jarosite (Jrs) and 6 wt. \% of illite (Ill); (b) altered Llandoverian shale from level 1, with 33 wt. \% of smectite (Sme), 65 wt. \% of halloysite $10 \AA$ (Hal) + halloysite $7 \AA$ (Hal) and 2 wt. \% of quartz (Qtz); (c) supergene veinlike mineralisation, in this case, exclusively composed by variscite (Var); (d) altered Llandoverian shale from level 6, with $2 \mathrm{wt}$. \% of smectite (Sme), $92 \mathrm{wt}$. \% of halloysite $10 \AA$ (Hal) + halloysite $7 \AA$ (Hal), 4 wt. \% of quartz (Qtz) and 2 wt. \% barite (Brt).

\subsection{Host Rocks}

The XRD study of bleached Llandoverian shales revealed halloysite, with lesser quartz and accessory jarosite. These shales do not show significant mineralogical variations between different 
levels in the profile (Table 1). Jarosite occurs in these shales replacing primary framboidal pyrite (Figure $6 \mathrm{a}-\mathrm{c}$ ). Jarosite crystals in these framboids are fine-grained (less than $5 \mu \mathrm{m}$ ) and have a rhombohedral shape (Figure 6a). Quartz and halloysite are cryptocrystalline.
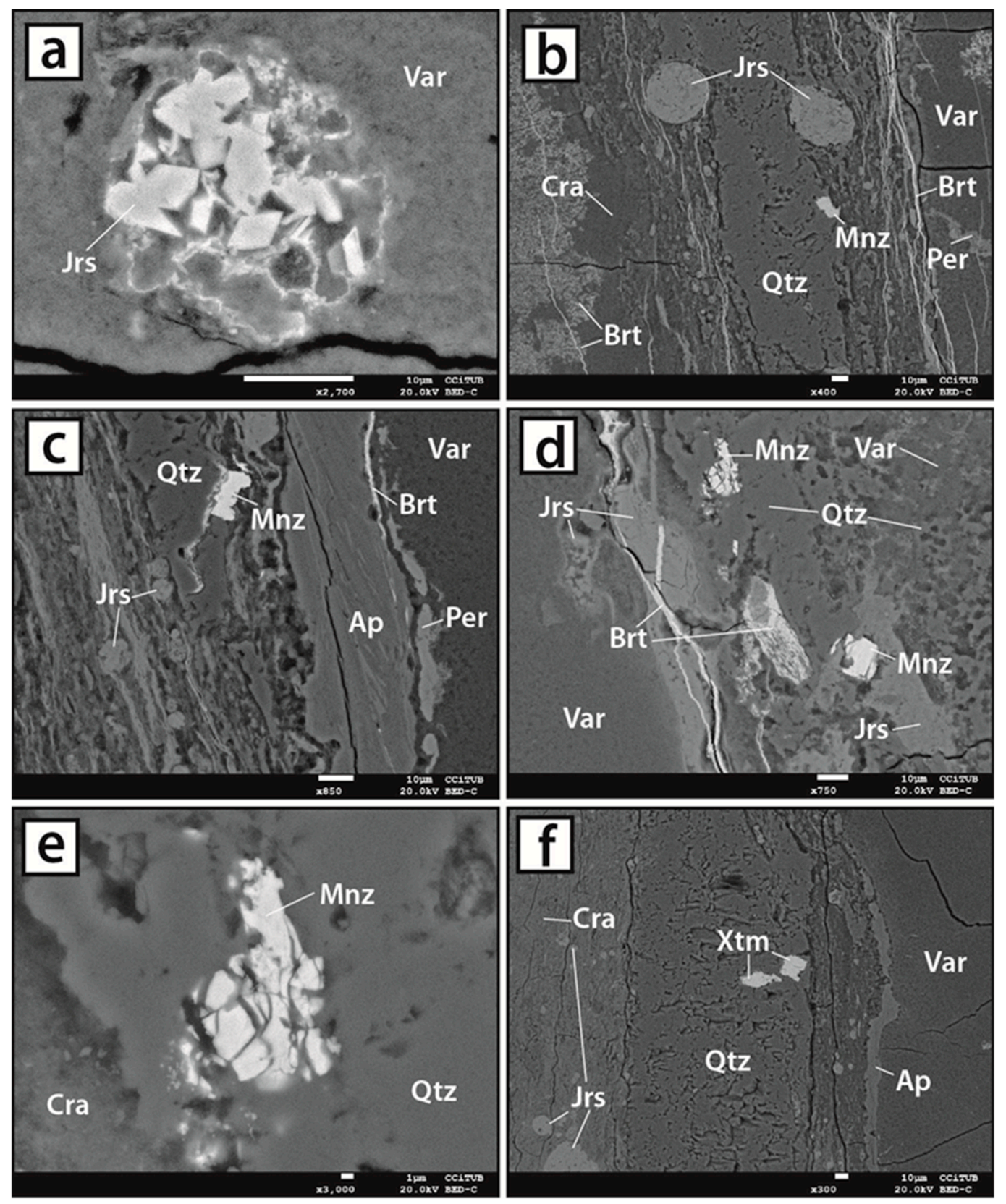

Figure 6. Mineralogical and textural features of Landoverian shales and associated supergene mineralisation; Scanning Electron Microscope (SEM)-backscattering electrons (BSE) images. (a) Pyrite framboid replaced by jarosite (Jrs), and finally by variscite (Var). Note the rhombohedral shape of the jarosite crystals; (b) Jarosite (Jrs) after pyrite framboids scattered in shales and chert (Qtz); Chert has disseminated monazite (Mnz); the ensemble is crosscut by baryte (Brt), variscite (Var), crandallite (Cra) and perhamite (Per) veins; (c) Similar to the image above, with an apatite vein (Ap); (d) Similar to the image above, with jarosite veins (Jrs); (e) Detail of the above image, showing monazite grains; (f) Xenotime grains (Xtm) scattered in chert beds.

Chert beds are mainly comprised of cryptocrystalline quartz with scattered organic matter, with minor pyrite framboids, and crystals of monazite-(Ce) and xenotime-(Y) (Figure 6b-f). 
Primary phosphate beds are made up of cryptocrystalline fluorapatite, also with dispersed, fine-grained organic matter and lesser amounts of pyrite framboids. Apatite beds may be replaced by supergene mineralisation along the weathering profile.

\subsection{Vein-like Supergene Mineralisation}

Textural studies of the supergene vein mineralisation revealed a complex sequence of vein infill. Two types of veins were found: on the one hand, containing smectite or Fe-rich phosphates dominant in the shallower parts of the profile (levels 1-4) and, on the other, veins of Al-rich phosphates, predominant in the deeper section of the deposit, especially between levels 4 and 7 (Figure 4f).

Smectite from shallower veins is commonly associated to significant amounts of halloysite, as well as minor quartz, jarosite, baryte and less abundant phosphosiderite and variscite (Table 1).

Vein infill in the Fe-rich phosphate assemblage consists of alternating cryptocrystalline, colloform bands of phosphosiderite and fluorapatite, each up to 20-30 $\mu \mathrm{m}$ thick, associated with, up to $5 \mu \mathrm{m}$-thick, cryptocrystalline quartz and jarosite bands (Figure 7a). In addition, some of these bands are crosscut by late bands infilled with halloysite and baryte, which may occur as elongated sections of tabular crystals up to $40 \mu \mathrm{m}$ long (Figure $7 \mathrm{a}, \mathrm{b}$ ).
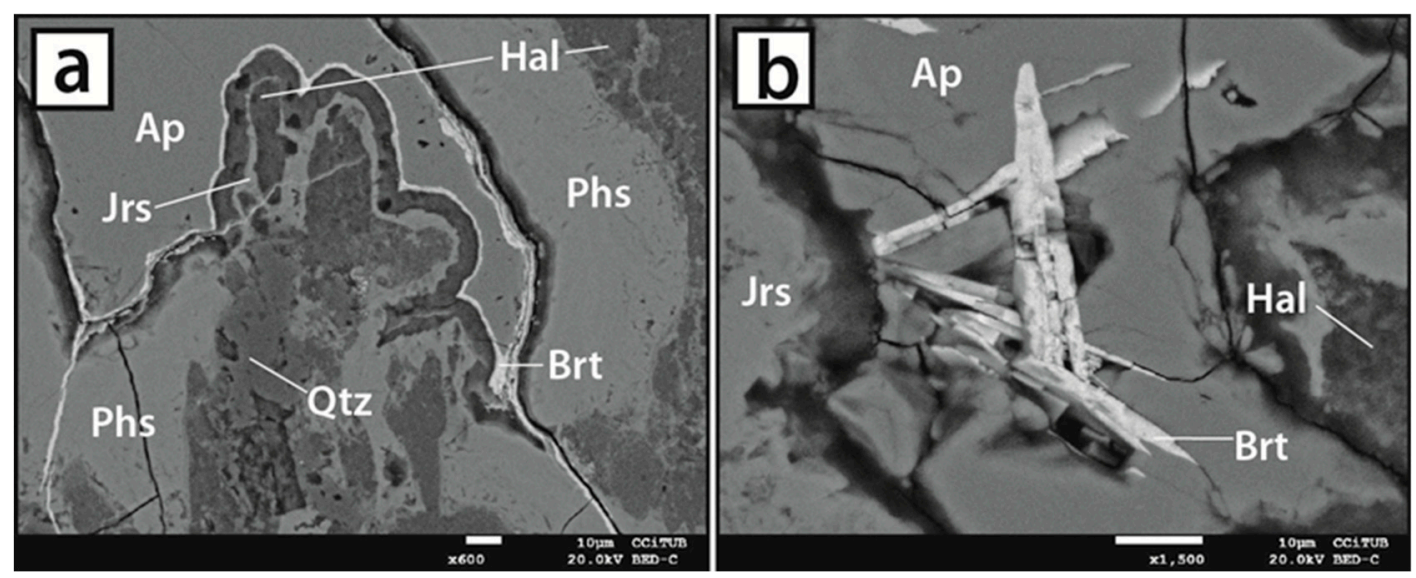

Figure 7. Detail of phosphate veins from upper levels. (a) Cryptocrystalline phosphosiderite (Phs) associated with fluorapatite (Ap), cryptocrystalline quartz (Qtz) and jarosite (Jrs) defining a colloform texture. It is also possible to distinguish microcrystalline halloysite (Hal) with fine bands of baryte (Brt) filling secondary cracks; (b) Detail of acicular aggregates of baryte (Brt) within a fluorapatite (Ap) vein associated with jarosite (Jrs) and halloysite (Hal).

In the case of the phosphate mineralisation of the deeper domains, XRD revealed that variscite is predominant (Figure 5) and is generally associated with jarosite and minor halloysite $(10 \AA)$. This variscite is cryptocrystalline and develops massive centimetric bands crosscut by perhamite veinlets (Figure $6 \mathrm{~b}, \mathrm{c}$ ). Crandallite also occurs as bands up to $100 \mu \mathrm{m}$ thick with disseminated microcrystalline grains of baryte (Figure $6 \mathrm{~b}-\mathrm{d}$; Table 1 ). In other cases, colloform fluorapatite bands up to $200 \mu \mathrm{m}$ thick can also be present (Figure 6c).

In all cases, variscite X-ray diffractograms fit with the XRD reference 00-025-0018 ("Powder Diffraction File, version 2; Joint Committee of Powder Diffraction Standards", 2000)—described by [44] as "Messbach-type, VM" variscite. This type of variscite presents an orthorhombic Pcab space group with the following lattice parameters: $a=9.90, b=9.65$ and $c=17.18 \AA$; and can be distinguished from "Lucin-type VL" variscite [44], which has a c parameter equal to $8.55 \AA$. The differences between both types of variscite are detected by XRD and infrared spectroscopy, and are caused by differences in water molecule distribution and in the symmetry of $\mathrm{PO}_{4}{ }^{3-}$ anions [44]. 
Table 1. Distribution and occurrence of mineral phases at different levels of the studied APGNM profile, according to XRD data (xxx: very abundant; xx: abundant; $x$ : less abundant; m: accessory).

\begin{tabular}{|c|c|c|c|c|c|c|c|c|c|c|c|c|}
\hline & Level & Variscite & Phosphosiderite & Crandallite & Jarosite & Baryte & Halloysite $10 \AA$ & Halloysite $7 \AA ̊$ & Alunite & Smectite & Quartz & Pyrite \\
\hline \multirow{7}{*}{$\begin{array}{c}\text { Altered } \\
\text { shales }\end{array}$} & 1 & & & & & & $x x x$ & & & $x x$ & $\mathrm{~m}$ & $\mathrm{~m}$ \\
\hline & 2 & & & & $\mathrm{x}$ & & $x x$ & & & & $x$ & $\mathrm{~m}$ \\
\hline & 3 & & & & & & $x x$ & & $\mathrm{x}$ & & $x$ & $\mathrm{~m}$ \\
\hline & 4 & & & & $\mathrm{x}$ & & $x x$ & & $x x$ & $x$ & $\mathrm{~m}$ & $\mathrm{~m}$ \\
\hline & 5 & & & & $\mathrm{x}$ & & $x x$ & & & & $\mathrm{x}$ & $\mathrm{m}$ \\
\hline & 6 & & & & & $\mathrm{~m}$ & $x$ & & $x$ & $\mathrm{x}$ & $\mathrm{m}$ & $\mathrm{m}$ \\
\hline & 7 & & & & & & $\mathrm{x}$ & & & & $x$ & $\mathrm{~m}$ \\
\hline \multirow{5}{*}{$\begin{array}{l}\text { Supergene } \\
\text { veins }\end{array}$} & 1 & $x$ & $x$ & & $x$ & $\mathrm{~m}$ & $x x$ & $\mathrm{x}$ & & $\mathrm{xxx}$ & $x$ & $\mathrm{~m}$ \\
\hline & 2 & $\mathrm{x}$ & $x$ & & $x x$ & $\mathrm{~m}$ & $\mathrm{x}$ & & & $x x x$ & $\mathrm{x}$ & $\mathrm{m}$ \\
\hline & 4 & $x x x$ & $x$ & & $x$ & & $x$ & & & & $\mathrm{x}$ & \\
\hline & 6 & $x x$ & & & $\mathrm{x}$ & $\mathrm{m}$ & $x$ & $x x$ & & $x$ & $\mathrm{x}$ & $\mathrm{m}$ \\
\hline & 7 & $x x x$ & & $x x$ & $\mathrm{x}$ & & & & & & & $\mathrm{m}$ \\
\hline
\end{tabular}




\subsection{Mineral Chemistry}

In the study area, variscite composition is quite variable, and the most remarkable changes are found in the $\mathrm{Fe}_{2} \mathrm{O}_{3}$ content, which corresponds to the solid solution variscite-strengite (Table 2). The high silica contents detected in some samples may be due to fine-grained admixtures of cryptocrystalline quartz. Sulphate content is very low, and minor elements such as V or Cr are below EPMA detection limits.

Phosphosiderite also contains $\mathrm{Al}$, however only in low proportions, less than $2.8 \mathrm{wt}$. \% $\mathrm{Al}_{2} \mathrm{O}_{3}$. The relatively high contents of $\mathrm{CaO}$ recorded in some samples can be due to admixtures of cryptocrystalline calcite or interstitial apatite, and to the occurrence of cryptocrystalline perhamite. Similarly, the high $\mathrm{SiO}_{2}$ amounts in cryptocrystalline perhamite can be explained by disseminations of cryptocrystalline quartz.

Halloysite may be relatively enriched in $\mathrm{Fe}^{3+}$, which may explain the greenish-brownish colour of the mineral in some veinlets.

\section{Bulk Rock Geochemistry}

Bulk rock composition of major and trace elements was analysed for the different lithologies of the Gavà profile; namely, Quaternary calcrete, altered Llandoverian shales and supergene mineralisation veins (Table 3).

The Quaternary calcrete level lies on top of the weathering profile and does not present any significant compositional anomalies. It contains $38.7 \mathrm{wt}$. \% $\mathrm{CaO}, \mathrm{SiO}_{2}$ contents of up to $12.24 \mathrm{wt}$. \%, 5.71 wt. $\% \mathrm{Fe}_{2} \mathrm{O}_{3}$ and 5.71 wt. $\% \mathrm{Al}_{2} \mathrm{O}_{3}$ (Table 3).

Llandoverian shale samples do not display any compositional anomalies that could be related to weathering. In general, they are mostly comprised of silica, with $\mathrm{SiO}_{2}$ contents ranging between 81.3 and 92.26 wt. \% (Table 3). $\mathrm{Al}_{2} \mathrm{O}_{3}$ contents are also high, related to the occurrence of phyllosilicates, and range between 3.3 and $8.6 \mathrm{wt}$. \%, while $\mathrm{Fe}_{2} \mathrm{O}_{3}$ contents are up to $4.41 \mathrm{wt}$. \%. The trace element composition of altered shales is marked by a general and significant enrichment in $\mathrm{V}$ (up to $718 \mathrm{ppm}$ ) and Ba (up to $1494 \mathrm{ppm}$ ). 
Table 2. Electron probe microanalyses (EPMA) analyses: representative composition of different supergene mineralisation phases.

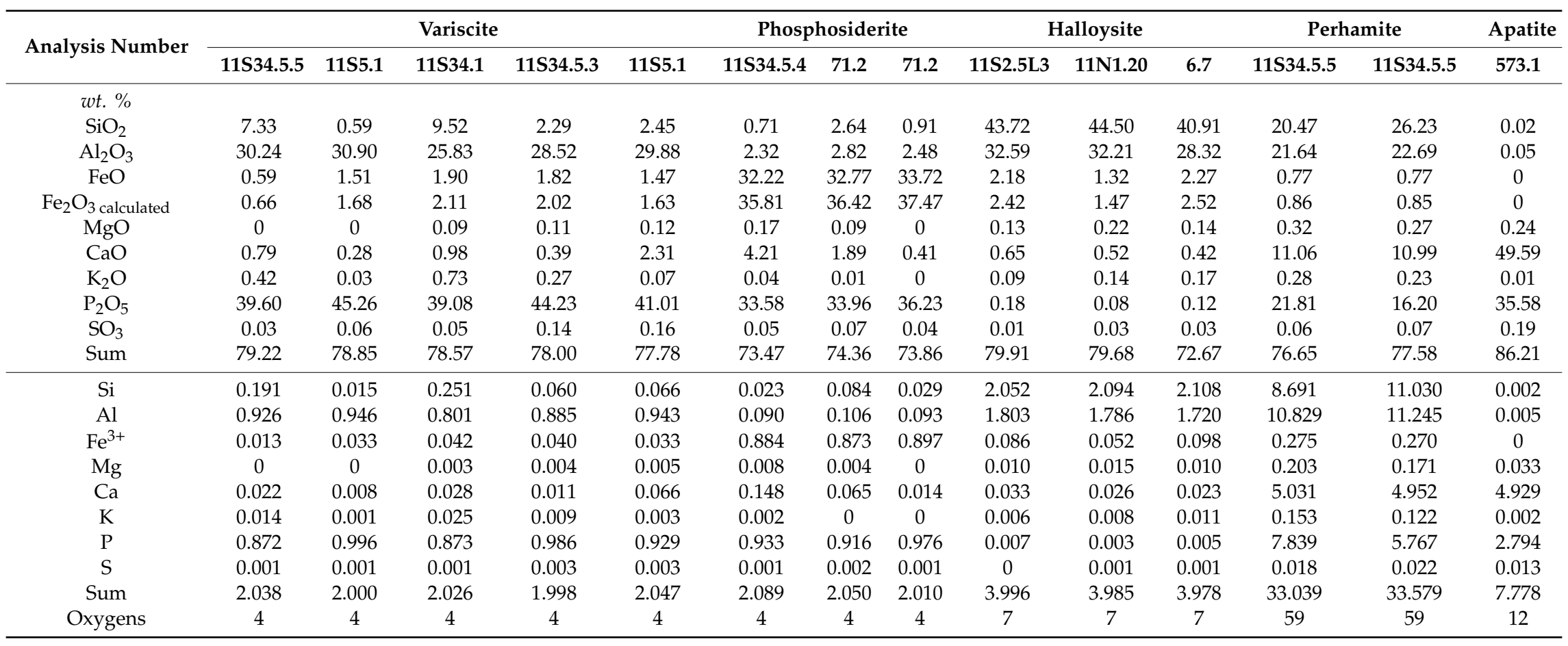


The composition of different phosphate veins hosted in Llandoverian shales has been analysed at different depths in the weathering profile. The deepest veins (between levels 3 and 7) are mainly comprised of variscite and are therefore mostly enriched in aluminium, with $\mathrm{Al}_{2} \mathrm{O}_{3}$ contents of 20.28 to 24.61 wt. \%. However, sample GAV 0.1 (Table 3), which was obtained at the mine entrance near the surface, is mainly composed of phosphosiderite. Accordingly, $\mathrm{Fe}_{2} \mathrm{O}_{3}$ contents are higher than $\mathrm{Al}_{2} \mathrm{O}_{3}$ contents; $32.85 \mathrm{wt}$. $\%$ and $3.26 \mathrm{wt}$. \%, respectively (Table 3 ).

In comparison with altered shales, the trace element composition of supergene phosphate veins is characterised by a significant enrichment in critical elements, such as Sc (up to $219 \mathrm{ppm}$ ), Ga (up to $72 \mathrm{ppm}$ ). In the case of REE, deeper samples of supergene phosphates (Figure 3) present a significant enrichment (up to $281.7 \mathrm{ppm} \sum \mathrm{REE}$ ) while shallower samples are impoverished in REE in comparison with hosted shales. Other elements such as Cr (up to $790 \mathrm{ppm}$ ), As (up to $852 \mathrm{ppm}$ ) or Sr (up to $491 \mathrm{ppm}$ ) are also significantly enriched in phosphate veins (Table 3).

REE diagrams show negative patterns for all the samples derived from the veins, except for phosphosiderite sample GAV 0.1 obtained at the uppermost levels (see above), which shows a positive pattern with a significant enrichment in Heavy Rare Earth Elements (HREE) (Figure 8a) and a marked negative Ce anomaly. Phosphate veins at the deepest levels show a neat positive anomaly in Pr and $\mathrm{Nd}$, and a general enrichment in Light Rare Earth Elements (LREE). Negative anomalies in Ce and Eu are also worth noting, and an Eu anomaly is also observed in altered shales and quaternary calcrete.

Trace element diagrams of different lithologies (Figure $8 b$ ) showed similar patterns between phosphate veins and altered shales. However, the shallowest phosphate veins are depleted in REE and High Field Strength Elements (HFSE; Nb, Ta, Zr and Hf) in comparison to the deepest. Other lithologies, including Quaternary calcrete, are depleted in Th and HFSE and are significantly enriched in $\mathrm{Ba}, \mathrm{U}, \mathrm{Pb}$, $\mathrm{Sr}$ and Eu (Figure 8b). 
Table 3. Representative bulk rock chemical analyses of the different lithologies occurring at the APGNM weathering profile. LOI: Loss on ignition.

\begin{tabular}{|c|c|c|c|c|c|c|c|c|c|c|c|c|c|}
\hline \multirow{2}{*}{ Sample } & \multirow{2}{*}{$\begin{array}{c}\text { Quaternary Calcrete } \\
\text { FGAV_TOR }\end{array}$} & \multicolumn{7}{|c|}{ Altered Shales } & \multicolumn{5}{|c|}{ Supergene Phosphates } \\
\hline & & 11NL1 & 11NL2 & 11NL3 & 11NL4 & 11NL5 & 11NL6 & 11NL7 & 0.1 & 3.9 & 4.0 & L4V & 6.1 \\
\hline \multicolumn{14}{|l|}{$w t . \%$} \\
\hline $\mathrm{SiO}_{2}$ & 12.24 & 81.31 & 89.63 & 92.83 & 91.69 & 82.49 & 92.26 & 88.05 & 5.49 & 14.04 & 15.03 & 9.40 & 7.08 \\
\hline $\mathrm{TiO}_{2}$ & 0.20 & 0.47 & 0.30 & 0.17 & 0.20 & 0.28 & 0.20 & 0.22 & 0.31 & 0.25 & 0.22 & 0.14 & 0.14 \\
\hline $\mathrm{Al}_{2} \mathrm{O}_{3}$ & 2.98 & 8.61 & 4.76 & 3.27 & 4.72 & 7.23 & 4.07 & 5.27 & 3.26 & 20.28 & 22.37 & 24.61 & 23.74 \\
\hline $\mathrm{Fe}_{2} \mathrm{O}_{3}$ & 5.71 & 1.74 & 0.72 & 0.72 & 0.37 & 4.41 & 1.01 & 0.91 & 32.85 & 8.70 & 5.22 & 6.91 & 8.61 \\
\hline $\mathrm{MnO}$ & 0.01 & 0.02 & 0.01 & 0.01 & 0.01 & 0.01 & 0.01 & 0.01 & 0.01 & 0.01 & 0.01 & 0.01 & 0.01 \\
\hline $\mathrm{MgO}$ & 0.59 & 0.92 & 0.46 & 0.26 & 0.44 & 0.59 & 0.32 & 0.45 & 0.21 & 0.18 & 0.16 & 0.10 & 0.09 \\
\hline $\mathrm{CaO}$ & 38.7 & 0.43 & 0.12 & 0.08 & 0.09 & 0.13 & 0.05 & 0.40 & 3.54 & 1.77 & 2.11 & 0.85 & 0.57 \\
\hline $\mathrm{Na}_{2} \mathrm{O}$ & 0.05 & 0.08 & 0.02 & 0.05 & 0.02 & 0.03 & 0.03 & 0.05 & 0.15 & 0.30 & 0.15 & 0.09 & 0.10 \\
\hline $\mathrm{K}_{2} \mathrm{O}$ & 1.78 & 2.35 & 1.24 & 0.8 & 1.17 & 1.80 & 0.98 & 1.25 & 0.03 & 0.20 & 0.30 & 0.49 & 0.70 \\
\hline $\mathrm{P}_{2} \mathrm{O}_{5}$ & 0.40 & 0.07 & 0.07 & 0.04 & 0.03 & 0.17 & 0.06 & 0.18 & 30.63 & 32.24 & 29.14 & 33.16 & 34.19 \\
\hline LOI & 33.77 & 4.52 & 1.76 & 1.18 & 1.43 & 2.68 & 1.40 & 2.20 & 22.58 & 21.40 & 23.75 & 22.40 & 23.08 \\
\hline Sum & 96.43 & 100.52 & 99.08 & 99.41 & 100.17 & 99.82 & 100.38 & 98.99 & 99.06 & 99.39 & 98.46 & 98.15 & 98.33 \\
\hline \multicolumn{14}{|l|}{ ppm } \\
\hline $\mathrm{Sc}$ & 9 & 11 & 6 & 3 & 6 & 8 & 5 & 6 & 49 & 219 & 113 & 208 & 203 \\
\hline V & 76 & 286 & 269 & 275 & 236 & 718 & 423 & 384 & 288 & 300 & 336 & 312 & 363 \\
\hline $\mathrm{Cr}$ & 120 & 60 & 50 & 30 & 30 & 70 & 40 & 50 & 790 & 340 & 280 & 770 & 720 \\
\hline Co & 1 & 8 & $<1$ & 1 & $<1$ & 4 & 1 & 1 & $<1$ & 1 & 4 & 2 & 5 \\
\hline $\mathrm{Ni}$ & $<20$ & 30 & $<20$ & $<20$ & $<20$ & 70 & $<20$ & $<20$ & $<20$ & $<20$ & 80 & 50 & 40 \\
\hline $\mathrm{Cu}$ & 40 & 50 & 10 & 20 & 10 & 150 & 30 & 40 & 230 & 40 & 340 & 90 & 100 \\
\hline $\mathrm{Zn}$ & $<30$ & $<30$ & $<30$ & $<30$ & $<30$ & $<30$ & $<30$ & 80 & $<30$ & $<30$ & 70 & $<30$ & $<30$ \\
\hline $\mathrm{Ga}$ & 14 & 17 & 9 & 7 & 8 & 13 & 9 & 10 & 29 & 20 & 15 & 72 & 69 \\
\hline $\mathrm{Ge}$ & $<1$ & 5 & 3 & 1 & 2 & 2 & 2 & 2 & $<1$ & $<1$ & 1 & 1 & $<1$ \\
\hline As & 98 & 16 & 10 & $<5$ & $<5$ & 51 & $<5$ & 6 & 852 & 192 & 219 & 631 & 714 \\
\hline $\mathrm{Rb}$ & 26 & 74 & 37 & 22 & 34 & 51 & 28 & 37 & $<2$ & 7 & 4 & 5 & 5 \\
\hline $\mathrm{Sr}$ & 256 & 29 & 32 & 17 & 13 & 37 & 19 & 47 & 309 & 442 & 452 & 430 & 491 \\
\hline $\mathrm{Y}$ & 11 & 37 & 28 & 11 & 10 & 33 & 16 & 19 & 22 & 13 & 3 & 19 & 20 \\
\hline $\mathrm{Zr}$ & 33 & 85 & 49 & 27 & 27 & 46 & 30 & 37 & 25 & 4 & 5 & 5 & 5 \\
\hline $\mathrm{Nb}$ & 3 & 9 & 6 & 4 & 4 & 5 & 4 & 5 & 3 & 1 & $<1$ & $<1$ & $<1$ \\
\hline Mo & 10 & 6 & 8 & 4 & 2 & 10 & 4 & 7 & 16 & 19 & 18 & 15 & 17 \\
\hline
\end{tabular}


Table 3. Cont

\begin{tabular}{|c|c|c|c|c|c|c|c|c|c|c|c|c|c|}
\hline \multirow{2}{*}{ Sample } & \multirow{2}{*}{$\begin{array}{c}\text { Quaternary Calcrete } \\
\text { FGAV_TOR }\end{array}$} & \multicolumn{7}{|c|}{ Altered Shales } & \multicolumn{5}{|c|}{ Supergene Phosphates } \\
\hline & & 11NL1 & $11 N L 2$ & 11NL3 & 11NL4 & 11NL5 & 11NL6 & 11NL7 & 0.1 & 3.9 & 4.0 & L4V & 6.1 \\
\hline In & 0.8 & $<0.2$ & $<0.2$ & $<0.2$ & $<0.2$ & $<0.2$ & $<0.2$ & $<0.2$ & 0.3 & 0.8 & 0.7 & 1.2 & 1.0 \\
\hline $\mathrm{Sb}$ & 2.8 & 7.2 & 5.7 & 2.4 & 2.8 & 6.3 & 2.8 & 5.4 & 51.2 & 7.5 & 3.5 & 12.1 & 13.1 \\
\hline Cs & 1.2 & 2.3 & 1.1 & 0.5 & 1.3 & 1.3 & 0.8 & 1.0 & $<0.5$ & $<0.5$ & $<0.5$ & $<0.5$ & $<0.5$ \\
\hline $\mathrm{Ba}$ & 747 & 1494 & 990 & 711 & 961 & 1398 & 822 & 1136 & 842 & 5150 & 5877 & 1785 & 1434 \\
\hline $\mathrm{La}$ & 25.5 & 52.1 & 43.6 & 15.0 & 11.9 & 31.2 & 17.3 & 22.2 & 2.6 & 18.7 & 5.2 & 32.0 & 36.9 \\
\hline $\mathrm{Ce}$ & 41.7 & 69.3 & 65.6 & 27.1 & 21.7 & 55.6 & 28.6 & 41.8 & 1.7 & 28.9 & 5.5 & 76.0 & 87.7 \\
\hline $\operatorname{Pr}$ & 5.9 & 8.7 & 9.3 & 3.4 & 2.6 & 7.1 & 3.8 & 5.4 & 0.4 & 4.3 & 0.6 & 17.2 & 21.4 \\
\hline $\mathrm{Nd}$ & 29 & 31 & 34 & 14 & 10 & 27 & 15 & 23 & 1 & 14 & 2 & 77 & 96 \\
\hline $\mathrm{Sm}$ & 5.0 & 4.4 & 5.8 & 2.5 & 1.7 & 6.6 & 3.4 & 5.7 & 0.4 & 2.6 & 0.5 & 15.0 & 16.9 \\
\hline $\mathrm{Eu}$ & 0.8 & 0.9 & 1.0 & 0.4 & 0.4 & 1.3 & 0.8 & 1.3 & 0.1 & 0.6 & 0.1 & 2.9 & 3.6 \\
\hline $\mathrm{Gd}$ & 2.8 & 3.2 & 4.0 & 1.8 & 1.5 & 4.6 & 2.9 & 5.0 & 0.9 & 2.4 & 0.6 & 8.9 & 10.0 \\
\hline $\mathrm{Tb}$ & 0.4 & 0.6 & 0.6 & 0.3 & 0.2 & 0.7 & 0.4 & 0.6 & 0.2 & 0.3 & $<0.1$ & 1.0 & 1.0 \\
\hline Dy & 2.0 & 4.0 & 3.9 & 1.7 & 1.3 & 4.5 & 2.6 & 3.3 & 2.1 & 1.9 & 0.5 & 4.0 & 4.5 \\
\hline Ho & 0.4 & 0.9 & 0.8 & 0.3 & 0.3 & 1.0 & 0.5 & 0.6 & 0.5 & 0.4 & 0.1 & 0.6 & 0.7 \\
\hline Er & 1.3 & 3.1 & 2.6 & 1.1 & 0.9 & 2.8 & 1.5 & 1.8 & 1.9 & 1.1 & 0.3 & 1.6 & 1.7 \\
\hline $\mathrm{Tm}$ & 0.2 & 0.5 & 0.4 & 0.2 & 0.2 & 0.4 & 0.2 & 0.3 & 0.4 & 0.2 & $<0.1$ & 0.2 & 0.2 \\
\hline $\mathrm{Yb}$ & 1.0 & 3.9 & 2.7 & 1.3 & 1.0 & 3.1 & 1.5 & 2.0 & 2.5 & 1.1 & 0.3 & 1.0 & 1.0 \\
\hline $\mathrm{Lu}$ & 0.14 & 0.7 & 0.4 & 0.2 & 0.2 & 0.5 & 0.2 & 0.3 & 0.4 & 0.2 & 0.1 & 0.1 & 0.1 \\
\hline Hf & 0.9 & 1.8 & 1.2 & 0.6 & 0.6 & 1.1 & 0.6 & 0.9 & 0.6 & 0.2 & 0.3 & $<0.2$ & 0.2 \\
\hline $\mathrm{Ta}$ & 0.2 & 0.7 & 0.4 & 0.2 & 0.3 & 0.4 & 0.3 & 0.4 & 0.1 & $<0.1$ & $<0.1$ & $<0.1$ & $<0.1$ \\
\hline $\mathrm{Pb}$ & 15 & 34 & 31 & 15 & 27 & 42 & 17 & 58 & 60 & 22 & 20 & 110 & 81 \\
\hline Th & 6 & 7.8 & 5.5 & 3.0 & 3.2 & 5.0 & 3.5 & 4.0 & 3.1 & 2.5 & 3.1 & 3.8 & 4.0 \\
\hline $\mathrm{U}$ & 2.4 & 5.2 & 4.9 & 3.7 & 2.5 & 7.0 & 3.8 & 5.5 & 4.2 & 6.0 & 6.4 & 12.8 & 8.3 \\
\hline$\Sigma \mathrm{REE}$ & 201.1 & 183.7 & 174.4 & 68.9 & 53.9 & 146.5 & 78.9 & 113.2 & 15.4 & 76.9 & 16.0 & 237.9 & 281.7 \\
\hline
\end{tabular}



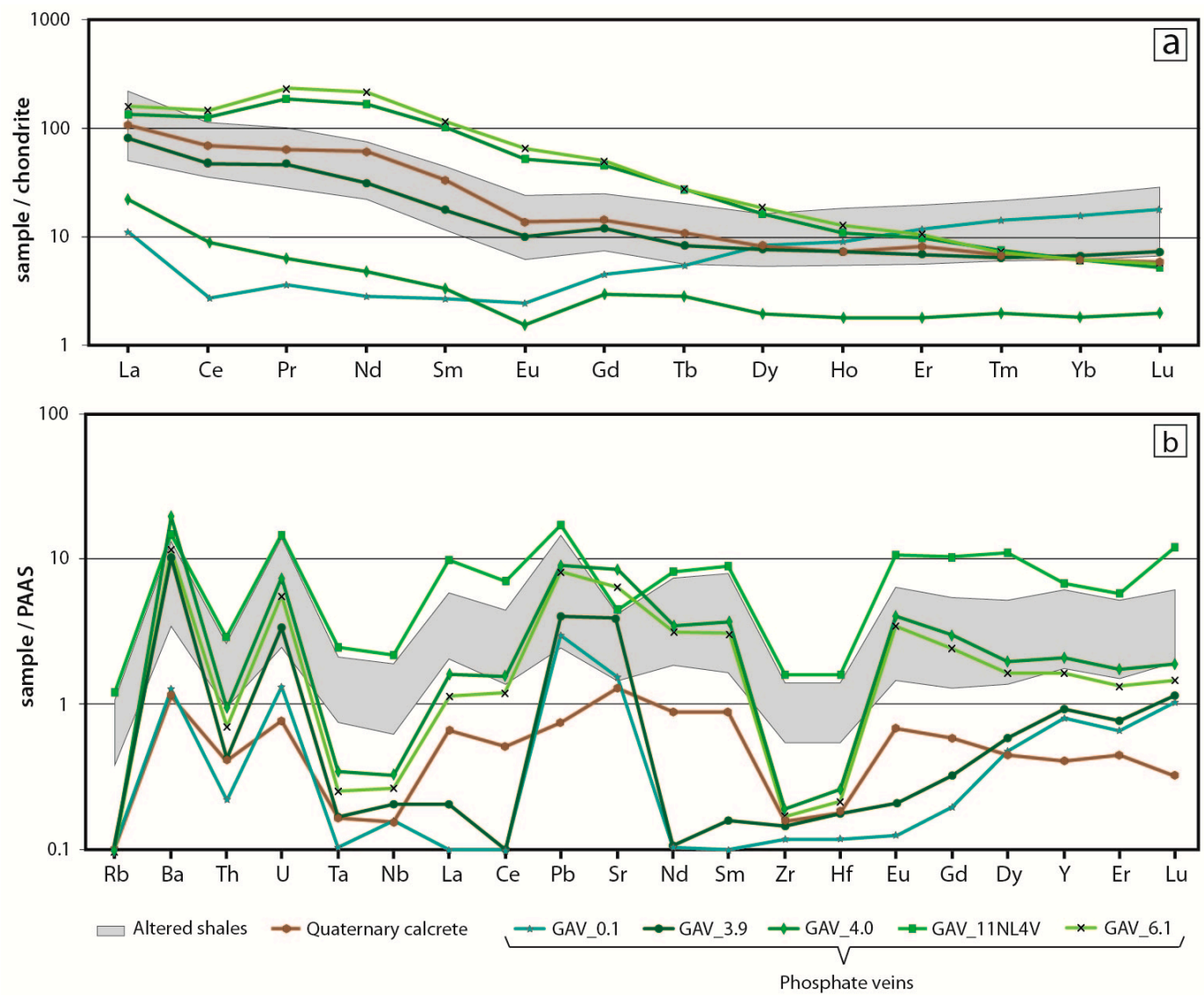

Figure 8. (a) REE plots of Llandoverian shales, Quaternary calcrete and supergene phosphate mineralisations of the Gavà weathering profile normalised to chondrite C1 (McDonough and Sun, 1995); (b) Multi-element trace element composition of the same lithologies normalised to the Post Archaean Australian Shales (PAAS; [45]).

\section{Discussion}

\subsection{Formation of the Gavà Supergene Mineralisations}

Llandoverian black shales are generally rich in organic matter and are typically dark in colour. However, in the Gavà deposits, they are strongly bleached due to weathering by percolating acidic and oxidising meteoric fluids during the early Pleistocene (1.20 $\pm 0.05 \mathrm{Ma}$; [21]). Similar bleaching processes developed in shales are reported worldwide [46-48].

This weathering process also generated the alteration of framboidal pyrite, which is abundant in the Llandoverian shales. Pyrite oxidation accounted for the acidic character of percolating fluids as well their enrichment in dissolved sulphate [49]. Such oxidation follows Reaction (1) [50], which is attested by the general replacement of pyrite by jarosite in Gavà [51,52]. (Figure 6).

$$
2 \mathrm{FeS}_{2}+7.5 \mathrm{O}_{2}+7 \mathrm{H}_{2} \mathrm{O} \rightarrow \text { goethite }+8 \mathrm{H}^{+}+4 \mathrm{SO}_{4}{ }^{2-}
$$

The action of these oxidised and acidic fluids $(\mathrm{pH}<3)$, as evidenced by the occurrence of alunite in supergene mineralisation [53]), promotes the alteration of sheet silicates in Llandoverian shales and also of the hosted syn-sedimentary phosphate beds. These processes lead to the corresponding enrichment of fluids in $\mathrm{Al}, \mathrm{Fe}$ and phosphate, respectively. This general fluid composition provides the basis to form secondary supergene phosphate-sulphate mineralisation within deeper cracks and fractures. Llandoverian shales are poor in $\mathrm{Ca}$, thus only minor Ca-bearing supergene phosphates and sulphates occur in Gavà, while the predominant supergene phases in this location are aluminium 
or iron bearing minerals (e.g., variscite, phosphosiderite, jarosite or alunite). The formation of these supergene phases occurs through a chemical Reaction (2) similar to that proposed by [50] for the formation of APS minerals such as variscite.

$$
\mathrm{Al}(\mathrm{OH})_{3}+\mathrm{HPO}_{4}{ }^{2-}+2 \mathrm{H}^{+} \rightarrow \text { variscite }+\mathrm{H}_{2} \mathrm{O}
$$

According to this reaction, the formation of supergene phases would be directly related to an increase of $\mathrm{pH}$ conditions. This $\mathrm{pH}$ variation would probably be associated with the circulation of these fluids to the deepest levels of the profile, where framboidal pyrite grains are not yet altered and thus do not generate acidification.

\subsection{Distribution of Critical Elements in Supergene Mineralisation}

Weathering processes in black shales have been systematically studied in the literature due to their potential as economical interest [54-58]. Elements such as $\mathrm{As}, \mathrm{Cd}, \mathrm{Co}, \mathrm{Cu}, \mathrm{Ni}, \mathrm{Pb}$, Sb or Ga may occur within the structure of framboidal pyrite [57,58]; while Cr or V may be found in clays and micas [59]).

The distribution of some critical trace elements was investigated in the different lithologies of the Gavà profile studied, and elemental anomalies that can be linked to the aforementioned supergene vein-like mineralisation were identified (Figure 9). In general, supergene veins in the Gavà deposits show significant enrichments in As, Ga, Sc and Ba (Figure 9a) and, to a lesser extent, in REE, In, $\mathrm{Co}$ and $\mathrm{Sb}$ (Figure $9 \mathrm{~b}$ ), with respect to their host rocks. In addition, $\mathrm{V}$ does not occur in significant concentrations in supergene veins, however, its contents in altered shales increase with depth, probably due to lixiviation and remobilisation as a result of weathering (Figure 9a).
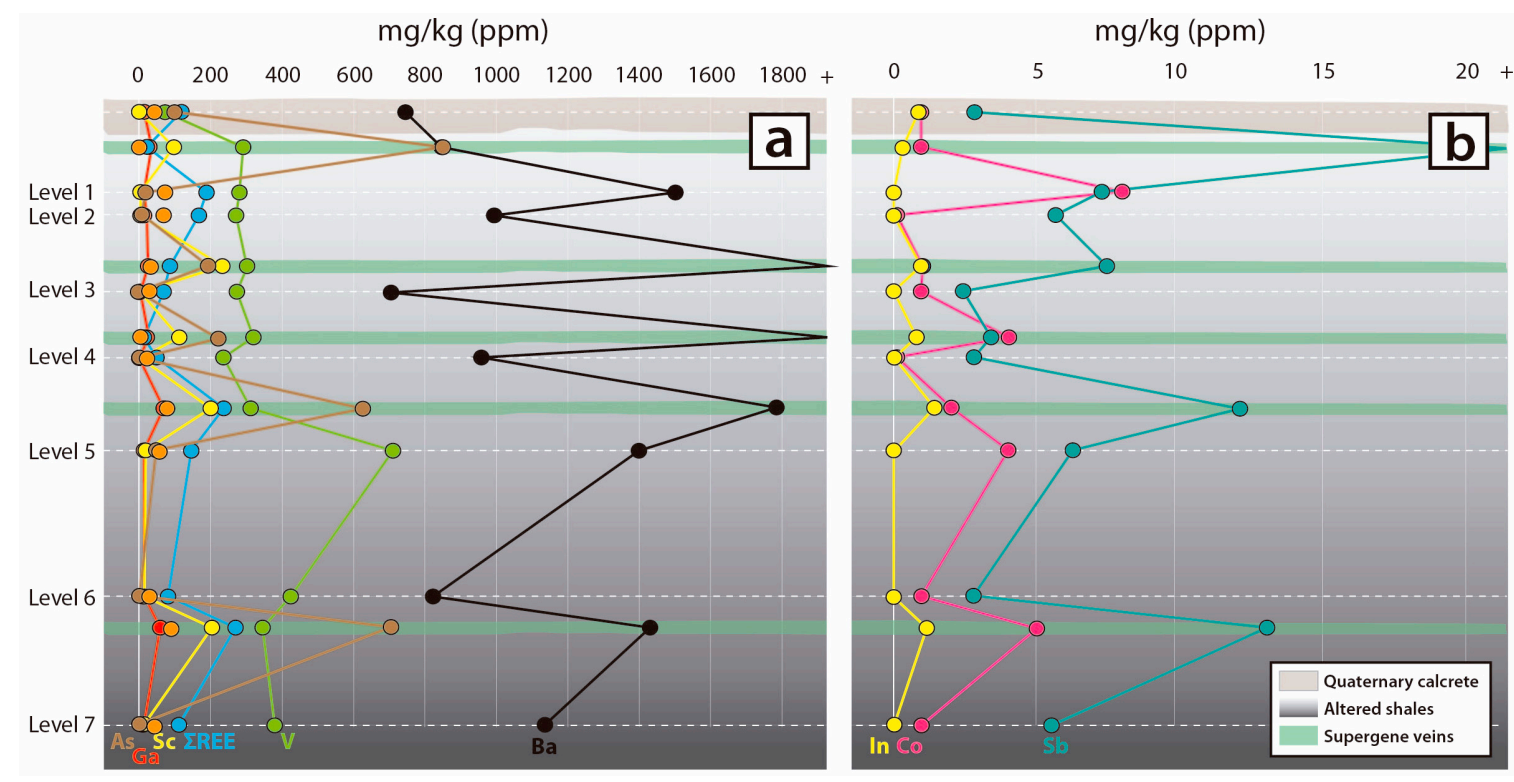

Figure 9. Plots of bulk rock chemical analyses of different Critical Elements (CE) associated to the studied profile: (a) Minor elements that include As, Ga, Sc, $\Sigma$ REE, V and Ba; (b) Trace elements including $\mathrm{In}, \mathrm{Co}$ and $\mathrm{Sb}$.

The solubility, lixiviation, and remobilisation of several critical metals by fluids at standard conditions $\left(\sim 25^{\circ} \mathrm{C}\right.$ and 1 bar $)$ are a matter of discussion [60]. However, the physicochemical conditions of the Gavà weathering fluids were seemingly very efficient in their mobilisation, since phosphate and/or sulphate dissolved in acid fluids $(\mathrm{pH}<3)$, may act as ligands and play an important role in their transport [61-64].

Therefore, in the case of the Gavà deposits, the critical elements mentioned above would have been mobilised by weathering of Llandoverian shale components and associated syn-sedimentary 
phosphates. The alteration of framboidal pyrite disseminated in shales would have released sulphate, some critical metals $[55,56]$ and lowered the $\mathrm{pH}$ of meteoric water. Ba would have been released after the alteration of phyllosilicates from Llandoverian shales, whereas REE and Sc would have been released from syn-sedimentary phosphate nodules [65].

The mobilisation of these CE within the fluid would be directly associated with the proportion of dissolved sulphate and phosphate contents. As, Co and $\mathrm{Sb}$ can be mobilised by sulphate in water [66-69]. This is also the case of REE and Sc, which are mobilised by sulphate-rich acid solutions, identified as a relevant ligand for REE in weathering environments [61-64,69].

Phosphate in solution also enhances the mobilisation of certain elements such as In and Ga, which are significantly soluble in phosphate-rich fluids. Phases such as $\mathrm{GaPO}_{4}$ (s) and $\mathrm{InPO}_{4}(\mathrm{~s})$ are generally more soluble and mobile than the corresponding oxyhydroxides [70]. Phosphate content in fluids can also play a significant role in the transport of REE and Sc along with sulphate ligands $[62,63]$. In addition, it should be also considered that REEs are significantly released during weathering, especially under tropical climate conditions [71].

The precipitation of the aforementioned elements is directly associated with the formation of supergene mineralisation. An increase in $\mathrm{pH}$ conditions at depth would generate the precipitation of supergene phases and the corresponding extraction of ligands from the fluid (e.g., sulphate and phosphate), also enabling the incorporation of these critical elements to the crystal lattice of the supergene phases [50]. The integrated model proposed for this process in the Gava area is graphically summarised in Figure 10.
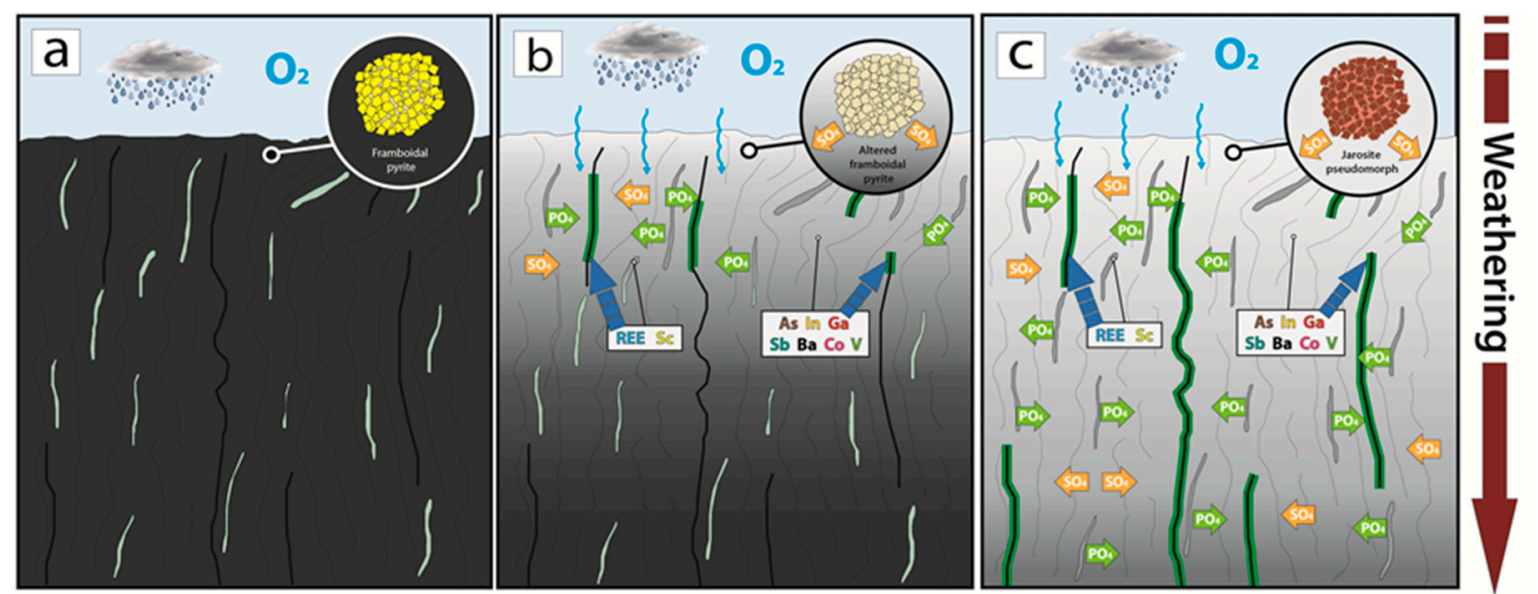

I $\square$ Time

Black shales

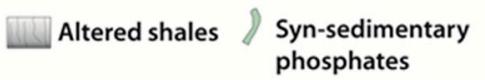
Altered syn-sedimentary
phosphates

| Fracture

Supergene mineralisation

Figure 10. Schematic model of the formation of supergene mineralisation in the APGNM: (a) Previous stage before weathering. Shales are still not altered and preserve their original black colour; (b) Initial stage of alteration. Weathering of organic matter generates bleaching of Llandoverian shales and the corresponding alteration of primary framboidal pyrite. Primary syn-sedimentary phosphates are also weathered and trigger the formation of supergene phosphate mineralisation; (c) Final stage of weathering. Llandoverian shales are mostly bleached and altered along with syn-sedimentary phosphates. Some chemical elements are lixiviated and may be accumulated in supergene mineralization. This is the case of REE, which come from Llandoverian shales that are lixiviated by the sulphates in solution due to the alteration of primary framboidal pyrite.

\subsection{Weathered Phosphates as Non-Conventional Source of Critical Elements}

Most of the mining programs related to CE exploration are still focused on conventional deposits including classical types such as carbonatites, peralkaline intrusives or pegmatites [72]. Recently, other 
geological environments have been explored and considered as potential non-conventional deposits of CE. This is the case of sedimentary phosphates [73], which are mainly comprised of minerals of the apatite group, and may contain REE and other potentially interesting elements, such as V, U, F, Cr, Se or $\mathrm{Sr}[16,65]$.

In addition, the extraction of certain CE from phosphates is relatively easy from a technical point of view. In the case of REE, for example, processes used in the treatment of phosphates to obtain phosphorus can also be applied to obtain REE as by-product [73]. Therefore, significant CE contents and their easy extraction means that sedimentary phosphate deposits worldwide should be considered as potential CE sources.

On the other hand, weathering has been proven an efficient process for concentrating certain CE. The present study illustrates this point, and economic concentrations of CE have been found in other weathering profiles, soils and laterites worldwide [8,10,11,74-77]. In fact, it is well known that the mineral structures of aluminophosphates of the alunite supergroup, such as florencite or goyazite, can concentrate REE at economic grades in lateritised carbonatites and karstic bauxites [74,78,79]. Similar enrichments at subeconomic grades are also described in other carbonatites [80] and kimberlites [81]. Gallium can also enter the structure of various aluminophosphates, typically by Al substitution, being dominant in some minerals such as galloplumbite [82]. Sc may also substitute $\mathrm{Al}$ and, in fact, kolbeckite $\left[\mathrm{ScPO}_{4} \cdot 2 \mathrm{H}_{2} \mathrm{O}\right]$ is isostructural with metavariscite [83]. $\mathrm{V}$ can also substitute $\mathrm{Al}$ in phosphates of the plumbogummite group, thus allowing the incorporation of $\mathrm{Ba}, \mathrm{Sr}, \mathrm{REE}$ and $\mathrm{Bi}$, among other elements [84].

The present study provides evidence of the supergene enrichment of critical elements in supergene phosphates produced by weathering. However, in the case of Gavà, their extremely limited tonnage and sensitive location (as a protected historical heritage site) forbids any mining endeavours in this area. Even so, this work contributes to the understanding of the mobilisation and concentration of $\mathrm{CE}$ by weathering processes in sedimentary phosphates.

The geological processes that control the distribution of CE in phosphates are still under debate [73], although weathering processes associated with phosphates after deposition play a significant role in the distribution of certain elements [85,86]. Sedimentary phosphates in certain climate areas undergo weathering processes that efficiently concentrate $\mathrm{CE}$, hence, such lithologies have potential as non-conventional CE deposits. This is the case of several worldwide localities of sedimentary phosphates and associated supergene mineralisations such as Altay-Sayan (Russia), Taiba and Lam-Lam (Senegal), Ruseifa (Jordan), Khourigba (Morocco), Florida (USA) or Arat (Israel), among others [87-96].

The concentrations of certain CE in this type of deposits are still not well reported. However, recent works report very significant contents of REE in sedimentary phosphate deposits, suggesting this type of deposit as a currently non-conventional resource of REE [64]. Therefore, we consider that concentration of certain CE in sedimentary phosphates and associated weathering mineralisation should be evaluated, taking into account that the present work in the Gavà deposits can be used as an example to determine exploration guidelines of CE in primary phosphates affected by weathering worldwide.

\section{Conclusions}

1. In the Gavà area, significant weathering processes involving acid and oxidising meteoric fluids occurred during the early Pleistocene affecting a series of Llandoverian black shales and associated syn-sedimentary phosphates.

2. Acid fluids would promote the alteration of phyllosilicates and disseminated framboidal pyrite in Llandoverian shales as well as associated beds of syn-sedimentary phosphates, producing a general enrichment of fluids in sulphate, $\mathrm{Fe}, \mathrm{Al}$ and phosphate, respectively.

3. The deposits of the Gavà area include supergene mineralisation distributed among veins that are hosted in weathered and bleached Llandoverian shales. They are mainly comprised of supergene phosphates (e.g., variscite, perhamite, crandallite, phosphosiderite), sulphates (e.g., jarosite, alunite) and associated clay minerals (e.g., halloysite and smectite). 
4. The supergene mineralisation is significantly enriched in certain CE. Such anomalous contents are related to the action of these acid and oxidised fluids associated with weathering.

5. Precipitation of supergene vein-like mineralisation is related to an increase of $\mathrm{pH}$ conditions in deeper parts of the profile. CE are hosted in the crystal lattice of supergene minerals.

6. Weathering processes and corresponding enrichment of $\mathrm{CE}$ in supergene mineralisation at the Gavà deposit can be used as an example to explore $\mathrm{CE}$ in primary phosphates affected by weathering worldwide.

Author Contributions: Conceptualization, Y.D.-A., M.C., J.C.M. and A.C.; Methodology, Y.D.-A., M.C., E.T., C.V.-d.-B. and S.E.J.-V.; Software, E.T. and S.E.J.-V.; Validation, Y.D.-A., M.C., J.B., J.C.M., A.C., C.V.-B.; Formal Analysis, Y.D.-A., M.C., E.T. and S.E.J.-V.; Investigation, Y.D.-A., M.C., J.C.M., A.C., I.D.-O., D.F.-L., A.A. and M.P.; Resources, J.B., M.C., J.C.M. and J.A.P.; Data Curation, Y.D.-A., E.T. and C.V.-d.-B.; Writing-Original Draft Preparation, M.C., Y.D.-A. and J.C.M.; Writing-Review \& Editing, Y.D.-A., M.C., A.C., J.C.M. and C.V.-d.-B.; Visualization, M.C.; Supervision, J.C.M., M.C. and A.C.; Project Administration, J.C.M., J.B., M.C., J.A.P. and E.T.; Funding Acquisition, Y.D.-A., M.C., E.T., J.B., J.C.M. and J.A.P. All authors have read and agreed to the published version of the manuscript.

Funding: This paper has been funded by projects 2014 SGR 1661 and 2014/100820 of the Generalitat de Catalunya.

Acknowledgments: We would like to thank to the Municipality of Gavà and the Museum of Gavà for their invaluable help in the study of the archaeological sites. Some of the samples used in this study were provided by the mineralogy collections of the Universitat de Barcelona and the Museu de Ciències Naturals de Barcelona. Xavier Llovet, David Artiaga, and Javier Veigas from the CCiT-UB provided assistance in the EPMA and SEM/FE-SEM analyses. Preparation of samples and thin sections were carried out by Gerard Lucena at the Laboratory of Geological and Paleontological Preparation of the Museu de Ciències Naturals de Barcelona.

Conflicts of Interest: The authors declare no conflict of interest.

\section{References}

1. European Commission. Report on critical raw materials or the EU. In Report of the Ad hoc Working Group on Defining Critical Raw Materials; European Commission: Brussels, Belgium, 2017; Available online: http://ec.europa.eu/DocsRoom/documents/10010/attachments/1/translations/en/renditions/native (accessed on 20 November 2019).

2. Chakhmouradian, A.R.; Wall, F. Rare earth elements: Rare earth elements: Minerals, mines, magnets (and more). Elements 2012, 8, 333-340. [CrossRef]

3. Hein, J.R.; Mizell, K.; Koschinsky, A.; Conrad, T.A. Deep-ocean mineral deposits as a source of critical metals for high- and green-technology applications: Comparison with land-based resources. Ore Geol. Rev. 2013, 51, 1-14. [CrossRef]

4. Weng, Z.; Jowitt, S.M.; Mudd, G.M.; Haque, N. A detailed assessment of global rare earth element resources: Opportunities and challenges. Econ. Geol. 2015, 110, 1925-1952. [CrossRef]

5. Graedel, T.E.; Harper, E.M.; Nassar, N.T.; Nuss, P.; Reck, B.K. Criticality of metals and metalloids. Proc. Natl. Acad. Sci. USA 2015, 112, 4257-4262. [CrossRef]

6. Binnemans, K.; Jones, P.T.; Müller, T.; Yurramendi, L. Rare earths and the balance problem: How to deal with changing markets? J. Sustain. Metall. 2018, 4, 126-146. [CrossRef]

7. Goodenough, K.M.; Schilling, J.; Jonsson, E.; Kalvig, P.; Charles, N.; Tuduri, J.; Deady, E.A.; Sadeghi, M.; Schiellerup, H.; Müller, A.; et al. Europe's rare earth element resource potential: An overview of REE metallogenetic provinces and their geodynamic settin. Ore Geol. Rev. 2016, 72, 838-856. [CrossRef]

8. Aiglsperger, T.; Proenza, J.A.; Zaccarini, F.; Lewis, J.F.; Garuti, G.; Labrador, M.; Longo, F. Platinum group minerals (PGM) in the Falcondo Ni laterite deposit, Loma Caribe peridotite (Dominican Republic). Mineral. Dep. 2015, 50, 105-123. [CrossRef]

9. Aiglsperger, T.; Proenza, J.A.; Lewis, J.F.; Labrador, M.; Svojtka, M.; Rojas-Purón, A.; Longo, F.; Durisová, J. Critical metals (REE, Sc, PGE) in Ni laterites from Cuba and the Dominican Republic. Ore Geol. Rev. 2016, 73, 127-147. [CrossRef]

10. Berger, A.; Janots, E.; Gnos, E.; Frei, R.; Bernier, F. Rare earth element mineralogy and geochemistry in a laterite profile from Madagascar. Appl. Geochem. 2014, 41, 218-228. [CrossRef] 
11. Eliopoulos, D.; Economou, G.; Tzifas, I.; Papatrechas, C. The potential of rare earth elements in Greece. In Proceedings of the 1st European Rare Earth Resources Conference ERES, Milos, Greece, 4-7 September 2014; pp. 308-316.

12. Gamaletsos, P.N.; Godelitsas, A.; Filippidis, A.; Pontikes, Y. The Rare Earth Elements Potential of Greek Bauxite Active Mines in the Light of a Sustainable REE Demand. J. Sustain. Metall. 2018, 5, 1-28. [CrossRef]

13. Hoshino, M.; Sanematsu, K.; Watanabe, Y. REE mineralogy and resources. In Handbook on the Physics and Chemistry of Rare Earths; Elsevier: Amsterdam, The Netherlands, 2016; Volume 49, pp. 129-291.

14. Mihajlovic, J.; Rinklebe, J. Rare earth elements in German soils-A review. Chemosphere 2018, 205, 514-523. [CrossRef] [PubMed]

15. Reinhardt, N.; Proenza, J.A.; Villanova-de-Benavent, C.; Aiglsperger, T.; Bover-Arnal, T.; Torró, L.; Salas, R.; Dziggel, A. Geochemistry and Mineralogy of Rare Earth Elements (REE) in Bauxitic Ores of the Catalan Coastal Range, NE Spain. Minerals 2018, 8, 562. [CrossRef]

16. Tzifas, I.T.; Godelitsas, A.; Magganas, A.; Androulakaki, E.; Eleftheriou, G.; Mertzimekis, T.J.; Perraki, M. Uranium-bearing phosphatized limestones of NW Greece. J. Geo. Exp. 2004, 143, 62-73. [CrossRef]

17. Walter, A.V.; Nahon, D.; Flicoteaux, R.; Girard, J.P.; Melfi, A. Behaviour of major and trace elements and fractionation of REE under tropical weathering of a typical apatite-rich carbonatite from Brazil. Earth Planet. Sci. Lett. 1995, 136, 591-596. [CrossRef]

18. Laveuf, C.; Cornu, S. A review on the potentiality of Rare Earth Elements to trace pedogenetic processes. Geoderma 2009, 154, 1-12. [CrossRef]

19. Sanematsu, K.; Moriyama, T.; Sotouky, L.; Watanabe, Y. Mobility of rare earth elements in basalt-derived laterite at the Bolaven Plateau, southern Laos. Resour. Geol. 2011, 61, 140-158. [CrossRef]

20. Camprubí, A.; Costa, F.; Melgarejo, J.C. Mineralizaciones de fosfatos férrico-alumínicos de Gavà (Catalunya): Tipología. Bol. Geol. Min. 1994, 105, 444-453.

21. Camprubí, A.; Melgarejo, J.C.; Proenza, J.A.; Costa, F.; Bosch, J.; Estrada, A.; Borrell, F.; Yushkin, N.P.; Andreichev, V.L. Mining and geological knowledge during the Neolithic: A geological study on the variscite mines at Gavà, Catalonia. Episodes 2003, 26, 295-301. [CrossRef]

22. Costa, F.; Camprubí, A.; Melgarejo, J.C. Aproximación geológica a las minas neolíticas de fosfatos férrico-alumínicos de Gavà (Cataluña). Bol. Geol. Min. 1994, 105, 436-443.

23. Gimeno, D.; Fernández-Turiel, J.L.; Villalba, M.J.; Edo, M.; Blasco, A. Complejo minero de Can Tintorer, Gavà: Geología y técnicas de explotación en el IV milenio. Rubricatum 1995, 1, $259-263$.

24. Melgarejo, J.C.; Cirera, M.C.; Proenza, J. Estudi geològic i mineralògic de mines de l'època neolítica a la Serra de Les Ferreres (Mines de Gavà). Rubricatum 2009, 4, 47-61.

25. Díaz-Acha, Y.; Melgarejo, J.C.; Bosch, J.; Andreazini, A.; Pastor, M.; Pujol-Solà, N.; Campeny, M.; Torró, L.; Villanova-de-Benavent, C.; Castillo-Oliver, M.; et al. The Neolithic variscite mines of Gavà, Catalonia: Criteria for mineral exploration and exploitation in the Prehistory. Bol. Soc. Geol. Mex. 2019, 71, 83-319. [CrossRef]

26. Alonso, M.; Edo, M.; Gordo, L.; Millán, M.; Villalba, M.J. Explotación minera neolítica en Can Tintoré (Gavà, Barcelona). Pyrenae 1978, 13-14, 7-14.

27. Villalba, M.J.; Bañolas, L.; Arenas, J.; Alonso, M. Les mines neolítiques de can Tintorer. Gavà. Excavacions 1978-1980: Barcelona, Catalonia, Departament de Cultura de la Generalitat de Catalunya. Excavacions Arqueològiques a Catalunya 1986, 6, 203.

28. Villalba, M.J.; Blasco, A.; Edo, M.; Bañolas, L.; Arenas, J. Minería neolítica: Can Tintorer, una aportación fundamental. Revista de Arqueología 1989, 96, 13-24.

29. Villalba, M.J.; Bañolas, L.; Arenas, J. Can Tintorer (Gavà, Catalunya): Une exploitation néolithique de phosphates et silicates. Cahiers du Quaternaire 1990, 17, 275-285.

30. Blasco, A.; Edo, M.; Villalba, M.J. Les perles en Callaïs du Sud de la France proviennent-elles des Mines de Can Tintorer? Le Chalcolithique en Languedoc, ses relations extra-regionales (Saint Mathieu de Tréviers, 1990). In Archéologie en Languedoc; Fédération Archéologique de l’Hérault: Hérault, France, 1991; pp. 279-289.

31. Blasco, A.; Villalba, M.J.; Edo, M. Cronologia del complex miner de Can Tintorer. Aportacions a la periodització del Neolític mitjà català. In 9è Col-loqui Internacional d'Arqueologia de Puigcerdà; Institut d'Estudis Ceretans: Puigcerdà, Spain, 1992; pp. 215-219.

32. Bosch, J.; Estrada, A.; Noain, M.J. Minería neolítica en Gavá (Baix Llobregat, Barcelona). Trabajos de Prehistoria 1996, 53, 59-71. [CrossRef] 
33. Villalba, M.J. Le gîte de variscite de Can Tintorer: Production, transformation, et circulation du minéral vert. In Matériaux, Productions, Circulations du Néolithique à L'âge du Bronze; Guilaine, J., Ed.; Éditions Errance: Paris, France, 2002; pp. 115-129.

34. Borrell, F.; Estrada, A. Elements ornamentals neolítics de variscita trobats a les mines 83 i 85 de Gavà, in. In Intervencions arqueològiques a les Mines de Gavà (sector serra de les Ferreres). Anys 1998-2009. De la variscita al ferro: Neolitic i antiguitat; Bosch, J., Borrell, F., Eds.; Rubricatum: Barcelona, Spain, 2009; Volume 4, pp. 171-181.

35. Borrell, F.; Orri, E. Excavacions arqueològiques a la serra de les Ferreres, Mines Prehistòriques de Gavà, in L'Arqueologia a Gavà. Homenatge a Alícia Estrada: Gavà, Catalonia, Ajuntament de Gavà/Amics del Museu de Gavà. Collecció La Nostra Gent 2009, 5, 67-86.

36. Borrell, F.; Bosch, J. Las minas de variscita de Gavà (Barcelona) y las redes de circulación en el Neolítico. Rubricatum 2012, 5, 315-322.

37. Blasco, M.; Borrell, M.; Bosch, J. Las minas prehistóricas de Gavà (Barcelona): Un ejemplo de estudio, conservación y presentación pública de un yacimiento arqueológico. Trabajos de Prehistoria 2000, 57, 77-87. [CrossRef]

38. Díaz-Acha, Y.; Campeny, M.; Melgarejo, J.C.; Bosch, J.; Lehbib, S.; Torró, L.; Proenza, J.A.; Castillo-Oliver, M.; Camprubí, A.; Villanova-de-Benavent, C.; et al. Geological context of the historic and prehistoric iron mines in the Gavà area, Catalonia, NE Iberian peninsula. Bol. Soc. Geol. Mex. 2019, 71, 321-342.

39. Anadón, P.; Colombo, F.; Esteban, M.; Marzo, M.; Robles, S.; Santanach, P.; Solé Sugrañés, L. Evolución tectonoestratigráfica de los Catalánides. Acta Geol. Hisp. 1979, 14, 242-270.

40. Guimerà, J. Palaeogene evolution of deformation in the north-eastern Iberian peninsula. Geol. Mag. 1984, 121, 413-420. [CrossRef]

41. Santanach, P.; Casas, J.M.; Gratacós, O.; Liesa, M.; Muñoz, J.A.; Sàbat, F. Variscan and Alpine structure of the hills of Barcelona: Geology in an urban area. J. Iber. Geol. 2011, 37, 121-136.

42. Julivert, M.; Duran, H. Paleozoic stratigraphy of the Central and Northern part of the Catalonian Coastal Ranges (NE Spain). Acta Geol. Hisp. 1990, 25, 3-12.

43. Julivert, M.; Duran, H.; Rickards, R.B.; Chapman, A.J. Siluro-Devonian graptolite stratigraphy of the Catalonian Coastal Ranges. Acta Geol. Hisp. 1985, 20, 199-207.

44. Salvador, P.; Fayos, J. Some aspects of the structural relationship between "Messbach-type" and "Lucin-type" variscites. Am. Miner. 1972, 57, 36-44.

45. Taylor, S.R. McLennan, S.M. The Continental Crust: Its Composition and Evolution; Blackwell: Oxford, UK, 1985.

46. Leythaeuser, D. Effects of weathering on organic matter in shales. Geochim. Cosmochim. Acta 1973, 37, 113-120. [CrossRef]

47. Clayton, J.L.; Swetland, P.J. Subaerial weathering of sedimentary organic matter. Geochim. Cosmochim. Acta 1978, 42, 305-312. [CrossRef]

48. Littke, R.; Klussmann, U.; Krooss, B.; Leythaeuser, D. Quantification of loss of calcite, pyrite and organic matter due to weathering of Toarcian black shales and effects on kerogen and bitumen characteristics. Geochim. Cosmochim. Acta 1991, 55, 3369-3378. [CrossRef]

49. Dill, H.G.; Busch, K.; Blum, N. Chemistry and origin o veinlike phosphate mineralization, Nuba Mts. (Sudan). Ore. Geol. Rev. 1991, 6, 9-24. [CrossRef]

50. Dill, H.G. The geology of aluminium phosphates and sulphates of the alunite group minerals: A review. Earth Sci. Rev. 2001, 53, 25-93. [CrossRef]

51. Wilkin, R.T.; Barnes, H.L. Formation processes of framboidal pyrite. Geoch. Cosm. Ac. 1996, 61, 323-339. [CrossRef]

52. Soliman, M.F.; El Goresy, A. Framboidal and idiomorphic pyrite in the upper Maastrichtian sedimentary rocks at Gabal Oweina, Nile Valley, Egypt: Formation processes, oxidation products and genetic implications to the origin of framboidal pyrite. Geoch. Cosm. Ac. 2012, 90, 195-220. [CrossRef]

53. Stroffregen, R.E.; Alpers, C.N. Woodhouseite and svanbergite in hydrothermal ore deposits: Products of apatite destruction during advanced alteration. Can. Min. 1987, 25, 201-211.

54. Petsch, S.T.; Berner, R.A.; Eglinton, T.I. A field study of the chemical weathering of ancient sedimentary organic matter. Org. Geochem. 2000, 31, 475-487. [CrossRef] 
55. Petsch, S.T.; Edwards, K.J.; Eglinton, T.I. Microbial transformation of organic matter in black shale and implications for global biogeochemical cycles. Palaeogeog. Palaeoclimatol. Palaeoecol. 2005, 219, 157-170. [CrossRef]

56. Liu, Y.; Zhang, J.; Tang, X.; Yang, C.; Tang, S. Weathering characteristics of the Lower Paleozoic black shale in northwestern Guizhou Province, south China. J. Earth Syst. Sci. 2016, 125, 1061-1078. [CrossRef]

57. Jambor, J.L.; Nordstrom, D.K.; Alpers, C.N. Metal-sulfate salts from sulfide mineral oxidation. In Sulfate Minerals_Crystallography, Geochemistry and Environmental Significance; Reviews in Mineralogy \& Geochemistry; Alpers, C.N., Jambor, J.L., Nordstrom, D.K., Eds.; Mineralogical Society of America: Washington, DC, USA, 2000; Volume 40, pp. 305-393.

58. Liu, F.; Liu, Z.; Li, Y.; Wilson, B.P.; Lundström, M. Behavior of gallium and germanium associated with zinc sulfide concentrate in oxygen pressure leaching. Phys. Prob. Min. Process. 2017, 53, 1047-1060.

59. Tuttle, M.L.W.; Breig, G.N.; Goldhaber, M.B. Weathering of the New Albany Shale, Kentucky: II. Redistribution of minor and trace elements. App. Geochem. 2009, 24, 1565-1578. [CrossRef]

60. Seward, T.M.; Williams-Jones, A.; Migdisov, A. The Chemistry of Metal Transport and Deposition by Ore-Forming Hydrothermal Fluids. Treatise Geochem. 2014, 13, 29-57.

61. Wood, S.A. The aqueous geochemistry of the rare-earth elements and yttrium. 1. Review of available low-temperature data for inorganic complexes and the inorganic REE speciation of natural waters. Chem. Geol. 1990, 82, 159-186. [CrossRef]

62. Migdisov, A.; Williams-Jones, A.; Brugger, J.; Caporuscio, F. Hydrothermal transport, deposition, and fractionation of the REE: Experimental data and thermodynamic calculations. Chem. Geol. 2016, 439, 13-42. [CrossRef]

63. Migdisov, A.; Guo, X.; Nisbet, H.; Xu, H.; Williams-Jones, A. Fractionation of REE, U, and Th in natural ore-forming hydrothermal systems: Thermodynamic modeling. J. Chem. Thermodyn. 2019, 128, 305-319. [CrossRef]

64. Andersson, S. Formation of Hydrothermal REE-Phosphate Deposits; Helsingin Yliopistö: Helsinki, Finland, 2019; p. 53.

65. Christmann, P. A forward look into rare earth supply and demand: A role for sedimentary phosphate deposits? Procedia Eng. 2014, 83, 19-26. [CrossRef]

66. Sherman, D.M.; Ragnarsdottir, K.V.; Oelkers, E.H. Antimony transport in hydrothermal solutions: An EXAFS study of antimony (V) complexation in alkaline sulfide and sulfide-chloride brines at temperatures from 25 ${ }^{\circ} \mathrm{C}$ to $300{ }^{\circ} \mathrm{C}$ at $\mathrm{P}_{\text {sat }}$. Chem. Geol. 2000, 167, 161-167. [CrossRef]

67. Krupka, K.M.; Serne, R.J. Geochemical Factors Affecting the Behavior of Antimony, Cobalt, Europium, Technetium, and Uranium in Vadose Sediments; Pacific Northwest National Laboratory: Washington, DC, USA, 2002; Volume PNNL-14126, p. 95.

68. Kim, Y.; Wolf, A.S.; Becker, U. Thermodynamic mixing properties of alunite supergroup minerals: Quantum-mechanical modeling and thermodynamic analysis of sulfate, chromate, selenate, phosphate, and arsenate solid solutions, as well as uranyl incorporation. Geochim. Cosmochim. Acta 2019, 248, 138-160. [CrossRef]

69. Orris, G.J.; Grauch, R.I. Rare Earth Element Mines, Deposits, and Occurrences; Open-File Report 02-189; US Geological Survey: Reston, VA, USA, 2002; p. 167.

70. Wood, S.A.; Samson, I.M. The aqueous geochemistry of gallium, germanium, indium and scandium. Ore Geol. Rev. 2006, 28, 57-102. [CrossRef]

71. Lixin, J.; Ma, L.; Dere, A.; White, T.; Mathur, R.; Brantley, S. REE mobility and fractionation during shale weathering along climate gradient. Chem. Geol. 2017, 466, 352-379.

72. Mariano, A.N.; Mariano, A.N., Jr. Rare earth mining and exploration in North America. Elements 2012, 8, 369-376. [CrossRef]

73. Emsbo, P.; McLaughin, P.I.; Breit, G.N.; du Bray, E.A.; Koenig, A.E. Rare earth elements in sedimentary phosphate deposits: Solution to the global REE crisis? Gondwana Res. 2015, 27, 776-785. [CrossRef]

74. Lottermoser, B.G. Rare-earth element mineralization within the Mt. Weld carbonatite laterite, Western Australia. Lithos 1990, 24, 151-167. [CrossRef]

75. Bao, Z.; Zhao, Z. Geochemistry of mineralization with exchangeable REY in the weathering crusts of granitic rocks in South China. Ore Geol. Rev. 2008, 33, 519-535. [CrossRef] 
76. Torró, L.; Proenza, J.A.; Aiglsperger, T.; Bover-Arnal, T.; Villanova-de-Benavent, C.; Rodríguez-García, D.; Ramírez, A.; Rodríguez, J.; Mosquea, L.A.; Salas, R. Geological, geochemical and mineralogical characteristics of REE-bearing Las Mercedes bauxite deposit, Dominican Republic. Ore Geol. Rev. 2017, 89, 114-131. [CrossRef]

77. Nechaev, V.P.; Chekryzhov, I.Y.; Vysotskiy, S.V.; Ignatiev, A.V.; Velivetskaya, T.A.; Tarasenko, I.A.; Agoshkov, A.I. Isotopic signatures of REY mineralization associated with lignite basins in South Primorye, Russian Far East. in: Special Issue on the Metallogeny of the Russian Far East. Ore Geol. Rev. 2018, 103, 68-77. [CrossRef]

78. Liu, X.; Wang, Q.; Zhang, Q.; Zhang, Y.; Li, Y. Genesis of REE minerals in the karstic bauxite in western Guangxi, China, and its constraints on the deposit formation conditions. Ore Geol. Rev. 2016, 75, 100-115. [CrossRef]

79. Proenza, J.A.; Aiglsperger, T.; Villanova-de-Benavent, C.; Torró, L.; Rodríguez, D.; Ramírez, A.; Rodríguez, J. Discovery of REE minerals hosted in karst bauxite ores from the Sierra de Bahoruco, Pedernales, Dominican Republic. In Proceedings of the 14th SGA Biennial Meeting, Québec City, QC, Canada, 20-23 August 2017; Volume 4, p. 5.

80. Giovannini, A.L.; Bastos, A.C.; Porto, C.G.; Pereira, V.P.; Takehara, L.; Barbanson, L.; Bastos, P.H.S. Mineralogy and geochemistry laterites from the Morro dos Seis Lagos Nb (Ti,REE) deposit (Amazonas, Brazil). Ore Geol. Rev. 2017, 88, 461-480. [CrossRef]

81. Makeev, B.A.; Makeev, A.B. Rare Earth and Strontium Aluminophosphates from the Vol-Vym Ridge of the Middle Timan. Geol. Ore Depos. 2011, 53, 657-662. [CrossRef]

82. Schlüter, J.; Malcherek, T.; Mihailova, B. Galloplumbogummite from Tsumeb, Namibia, a new member of the alunite group with tetravalent charge balance. N. Jahrb. Mineral. Abh. 2014, 191, 301-309. [CrossRef]

83. Yang, H.; Li, C.; Jenkins, R.A.; Downs, R.T.; Costin, G. Kolbeckite, $\mathrm{ScPO}_{4} \cdot 2 \mathrm{H}_{2} \mathrm{O}$, isomorphous with metavariscite. Acta Cryst. 2007, 63, 91-92. [CrossRef]

84. Bayliss, P.; Kolitsch, U.; Nickel, E.H.; Pring, A. Alunite supergroup: Recommended nomenclature. Min. Mag. 2010, 74, 919-992. [CrossRef]

85. Shields, G.A.; Stille, P. Diagenetic constraints on the use of cerium anomalies as palaeoseawater redox proxies: An isotopic and REE study of Cambrian phosphorites. Chem. Geol. 2001, 175, 29-48. [CrossRef]

86. Shields, G.A.; Webb, G.E. Has the REE composition of seawater changed over geological time? Chem. Geol. 2004, 204, 103-107. [CrossRef]

87. Slansky, M.; Lallemand, A.; Millot, G. La sédimentation et l'altération latéritique des formations phosphatées du gisement de Taïba (République du Sénégal). Bull. Serv. Géol. Alsace Lorraine 1965, 17, 311-324. [CrossRef]

88. Zanin, Y.N. Zones of lateritic weathering of secondary phosphorites of Altay-Sayan region. Int. Geol. Rev. 1968, 10, 1119-1127. [CrossRef]

89. Flicoteaux, R.; Nahon, D.; Paquet, H. Génèse des phosphates alumineux à partir des sédiments argilo-phosphatés du Tertiaire de Lam-Lam (Sénégal): Suite minéralogique. Permanences et changements de structures. Sci. Géol. Bull. 1977, 30, 153-174. [CrossRef]

90. Flicoteaux, R. Genese des phosphates alumineux du Sengal occidental, etapes et guides de l'alteration. Sci. Geol. Mem. 1982, 67, 292-317.

91. Nriagu, J.O.; Moore, P.B. Phosphate Minerals; Springer: Berlin, Germany, 1984; 442p.

92. Zohar, E.; Moshkovitz, S. A Campanian-Maastrichtian unconformity in the Arad Basin, NE Negev, Israel. Geol. Sur. Israel Cur. Res. 1983, 1984, 56-59.

93. Van Kauwenbergh, S.J.; Cathcart, J.B.; McClelian, G.H. Mineralogy and alteration of the phosphate deposits of Florida. US Geol. Surv. Bull. 1990, 1914, 45.

94. Abed, A.M.; Kraishan, G.M. Evidence for shallow marine origin of a Monterey-Formation-Type chert phosphorite dolomite sequence: Amman Formation (Late Cretaceous) central Jordan. Facies 1991, 24, 25-38. [CrossRef]

95. Trappe, J. Stratigraphy, facies distinction and paleogeography of the marine Paleogene from the western High Atlas, Morocco. Ne. Jah. Geol. Pal. Abh. 1991, 180, 279-321.

96. Prian, J.P. Phosphate deposits of the Senegal-Mauritania-Guinea Basin (West Africa): A review. Procedia Eng. 2014, 83, 27-36. [CrossRef]

(C) 2019 by the authors. Licensee MDPI, Basel, Switzerland. This article is an open access article distributed under the terms and conditions of the Creative Commons Attribution (CC BY) license (http://creativecommons.org/licenses/by/4.0/). 